\title{
Biogenic amines: Concentrations in serum and skeletal muscle from late pregnancy until early lactation in dairy cows with high versus normal body condition score
}

\author{
M. H. Ghaffari, ${ }^{1}$ H. Sadri, ${ }^{2 *} \dagger$ K. Schuh, ${ }^{1,3}$ G. Dusel, ${ }^{3}$ Dörte Frieten, ${ }^{3}$ C. Koch, ${ }^{4}$ C. Prehn, ${ }^{5}$ J. Adamski, ${ }^{5,6,7}$ \\ and H. Sauerwein ${ }^{1}$ \\ ${ }^{1}$ Institute of Animal Science, Physiology and Hygiene Unit, University of Bonn, 53115 Bonn, Germany \\ ${ }^{2}$ Department of Clinical Science, Faculty of Veterinary Medicine, University of Tabriz, 516616471 Tabriz, Iran \\ ${ }^{3}$ Department of Life Sciences and Engineering, Animal Nutrition and Hygiene Unit, University of Applied Sciences Bingen, \\ 55411 Bingen am Rhein, Germany \\ ${ }^{4}$ Educational and Research Centre for Animal Husbandry, Hofgut Neumuehle, 67728 Muenchweiler an der Alsenz, Germany \\ ${ }^{5}$ Institute of Experimental Genetics, Genome Analysis Center, Helmholtz Zentrum München, German Research Center for Environmental Health, \\ 85764 München-Neuherberg, Germany \\ ${ }^{6}$ Lehrstuhl für Experimentelle Genetik, Technische Universität München, 85350 Freising-Weihenstephan, Germany \\ ${ }^{7}$ German Center for Diabetes Research (DZD), 85764 München-Neuherberg, Germany
}

\section{ABSTRACT}

Biogenic amines (BA) are a class of nitrogenous compounds that are involved in a wide variety of physiological processes, but their role in transition cows is poorly understood. Our objectives were to describe the longitudinal changes of BA in serum and in skeletal muscle during the transition period and to characterize temporal responses of $\mathrm{BA}$ in relation to body condition score (BCS) of periparturient dairy cows. Fifteen weeks before calving, 36 multiparous Holstein cows were assigned to 2 groups ( $\mathrm{n}=18$ per group) that were fed differently to reach either high [HBCS; net energy for lactation $\left(\mathrm{NE}_{\mathrm{L}}\right)=7.2 \mathrm{MJ} / \mathrm{kg}$ of dry matter $\left.(\mathrm{DM})\right]$ or normal BCS (NBCS; $\mathrm{NE}_{\mathrm{L}}=6.8 \mathrm{MJ} / \mathrm{kg}$ of DM) at dryoff. The targeted BCS and back fat thickness (BFT) at dry-off (HBCS, $>3.75$ and $>1.4 \mathrm{~cm}$; NBCS, $<3.5$ and $<1.2 \mathrm{~cm}$ ) were reached. Thereafter, both groups were fed identical diets. Blood samples and muscle (semitendinosus) biopsies were collected at $\mathrm{d}-49,+3,+21$, and +84 relative to parturition. In serum and skeletal muscle, BA concentrations were measured using a targeted metabolomics assay. The data were analyzed as a repeated measure using the MIXED procedure of SAS. The serum concentrations of most BA (i.e., creatinine, taurine, carnosine putrescine, spermine, $\alpha$-aminoadipic acid, acetylornithine, kynurenine, serotonin, hydroxyproline, asymmetric dimethylarginine, and symmetric

Received November 22, 2018.

Accepted March 18, 2019.

*Corresponding author: sadri@tabrizu.ac.ir

$\dagger$ H. Sadri was a visiting scientist at the Institute of Animal Science, Physiology and Hygiene Unit, University of Bonn, 53115 Bonn, Germany at the time the research was done. dimethylarginine) fluctuated during the transition period, while others (i.e., spermidine, phenylethylamine) did not change with time. The muscle concentrations of BA remained unchanged over time. Creatinine had the highest concentrations in the serum, while carnosine had the highest concentration among the muscle BA. The serum concentrations of creatinine $(d+21)$, putrescine $(\mathrm{d}+84), \alpha$-aminoadipic acid $(\mathrm{d}+3)$, and hydroxyproline $(\mathrm{d}+21)$ were or tended to be higher for HBCS compared with NBCS postpartum. The serum concentrations of symmetric dimethylarginine (d $-49)$ and acetylornithine $(\mathrm{d}+84)$ were or tended to be lower for HBCS compared with NBCS, respectively. The serum kynurenine/tryptophan ratio was greater with HBCS than with NBCS $(\mathrm{d}+84)$. Compared with NBCS, HBCS was associated with lower muscle concentrations of carnosine, but those of hydroxyproline were higher $(\mathrm{d}-49)$. In both serum and muscle, the asymmetric dimethylarginine concentrations were greater with HBCS than with NBCS (d -49). No correlation was found between serum and skeletal muscle BA. This study indicates that overconditioning of dairy cows may influence serum and muscle BA concentrations in the periparturient period.

Key words: body condition score, biogenic amines, transition cows

\section{INTRODUCTION}

Biogenic amines (BA) are basic nitrogenous compounds formed by microbes, plants, and animals mainly through decarboxylation of amino acids or by amination and transamination of aldehydes and ketones (Medina et al., 2003). In unfermented food, the presence of BA indicates microbial spoilage and is thus undesired. 
With respect to dairy foods, accumulation of $\mathrm{BA}$ in cheese, particularly histamine, tyramine, putrescine, and to a lesser extent cadaverine, is considered a risk to consumers' health (Linares et al., 2011). However, BA also comprise compounds that are physiological part of endogenous regulation processes for example, catecholamines such as adrenaline or dopamine function as hormones and neurotransmitters. Through the activation of trace amine-associated receptor 1, some BA (comprising phenethylamines, e.g., tyramine) also have a role in transmission in dopaminergic, adrenergic, and serotonergic neurons in the central nervous system (Miller, 2011).

Biogenic amines, particularly polyamines (spermidine and spermine, as well as their precursor putrescine), have been associated with beneficial effects on human health because of their antioxidant and anti-inflammatory attributes (Lagishetty and Naik, 2008). They are involved in essential cellular functions, including cell proliferation and differentiation (Kalač and Krausová, 2005) and in adipogenesis (Vuohelainen et al., 2010). Several studies have also pointed to a role of polyamines in glucose utilization, insulin sensitivity, and fat oxidation (Lockwood and East, 1974; Sadasivan et al., 2014). However, the concentrations of polyamines generally decline with aging in most organisms, and this decline has been associated with several age-related health disorders in humans (Handa et al., 2018). Polyamines have been suggested as possibly increasing longevity via stimulation of the autophagic turnover of cytoplasmic organelles or aged proteins (Madeo et al., 2010). Our knowledge about BA in ruminants is mostly limited to dietary BA (Steidlová and Kalač, 2002, 2003) and the ruminal concentrations of BA in dairy cows (Ametaj et al., 2010; Saleem et al., 2012) or their effects on digestive function (Phuntsok et al., 1998; Wang et al., 2013). In contrast, little is known about the BA concentrations in blood or tissues of dairy cattle. Previous reports have suggested that ruminal microorganisms extensively metabolize dietary amines, and thus lower levels of exogenous amines can potentially be absorbed than contained in the diet (Phuntsok et al., 1998). Recently, Huber et al. (2016) found that elevated plasma concentrations of anti-inflammatory and antioxidative BA (i.e., carnosine, sarcosine, and spermidine) of transition cows were associated with increased productive lifespan.

As reported previously from this animal experiment (Schuh et al., 2019), cows calving with high BCS were metabolically challenged during early lactation because of a more severe negative energy balance and high mobilization of body reserves, mainly lipids and to some extent proteins. In addition, high BCS at calving was associated with compromised antioxidative capacity, reflected by numerically higher values of derivatives of reactive oxygen metabolites as well as lower values of total ferric reducing antioxidant power. In view of antioxidant and anti-inflammatory attributes of BA (Lagishetty and Naik, 2008), we hypothesized that overconditioning at calving may be accompanied by altered BA profiles, particularly polyamines, in the blood of transition cows. We also hypothesized that the concentrations of BA is serum would correlate with those in skeletal muscle during the extensive mobilization of body reserves in early lactation. Therefore, we quantified the BA concentrations in blood serum and in skeletal muscle tissue of Holstein cows during late gestation and early lactation using a targeted metabolomics approach and investigated whether overconditioning at calving altered these compared with normalconditioned cows.

\section{MATERIALS AND METHODS}

\section{Animals, Treatments, and Experimental Design}

The experiment was conducted at the Educational and Research Center for Animal Husbandry, Hofgut Neumuehle, Muenchweiler an der Alsenz, Germany. All animal experiments were performed in accordance with the German Animal Welfare Act and were approved by the local authority for animal welfare affairs (Landesuntersuchungsamt Rheinland-Pfalz, G 14-20-071), Koblenz, Germany. The basic setup of the trial with the performance results as well as the data of "classical" variables assessed in blood serum was described by Schuh et al. (2019). In brief, 36 multiparous German Holstein cows were classified 15 wk before their expected calving date as either normal-conditioned (NBCS; $\mathrm{n}=18$; average parity: $2.42 \pm 1.84$, mean $\pm \mathrm{SD}$ ) or high-conditioned (HBCS; $\mathrm{n}=18$; average parity: 3.37 \pm 1.67 , mean $\pm \mathrm{SD}$ ) cows. From wk 15 to 7 before the anticipated calving date, NBCS cows were fed a lowenergy ration $\left(\mathrm{NE}_{\mathrm{L}}=6.8 \mathrm{MJ} / \mathrm{kg}\right.$ of $\left.\mathrm{DM}\right)$, while HBCS cows were fed a high-energy ration $\left(\mathrm{NE}_{\mathrm{L}}=7.2 \mathrm{MJ} /\right.$ $\mathrm{kg}$ of DM) (Supplemental Table S1; https://doi.org/10 $.3168 /$ jds.2018-16034) as described previously (Schuh et al., 2019) to reach different targets for BCS and back fat thickness (BFT) at dry-off (HBCS, $>3.75$ and $>1.4$ $\mathrm{cm}$; NBCS, $<3.5$ and $<1.2 \mathrm{~cm})$. Cows were initially preselected from the entire herd (150 lactating cows) by their history of body condition (i.e., using BCS and BFT records from the preceding lactation). The preselected cows were also stratified for comparable milk yields (NBCS, 10,361 $\pm 302 \mathrm{~kg}$; HBCS, 10,315 $\pm 437 \mathrm{~kg}$ ). During the dry period and the subsequent lactation, all cows were fed the same diet as TMR. The diets were formulated according to the recommendations of the 
German Society of Nutrition Physiology (GfE, 2001). Both BCS and BFT were continuously monitored by 1 person every 2 wk during the entire period of the trial (15 wk antepartum to $12 \mathrm{wk}$ postpartum).

\section{Sampling and Laboratory Analyses}

Feed sampling was carried out as described previously (Schuh et al., 2019). The nutrient composition of the feed samples was analyzed according to the official recommendations of the Association of German Agricultural Analytic and Research Institutes (Naumann and Bassler, 2004). Samples were analyzed for DM, crude ash, CP, utilizable $\mathrm{CP}$, crude fat, crude fiber, $\mathrm{ADF}, \mathrm{NDF}$, and NFC, whereas the minerals $\mathrm{Ca}, \mathrm{P}$, $\mathrm{Mg}, \mathrm{Na}$, and $\mathrm{K}$ were analyzed by $\mathrm{x}$-ray fluorescence analysis. The energy content of the diet $\left(\mathrm{ME}\right.$ and $\left.\mathrm{NE}_{\mathrm{L}}\right)$ was calculated according to GfE (2009).

Blood samples were collected from the vena caudalis mediana before the morning feeding on $\mathrm{d}-49$ ( $\mathrm{SD}=$ $5.3),+3(\mathrm{SD}=1.6),+21(\mathrm{SD}=1.8)$, and $+84(\mathrm{SD}$ $=1.7$ ) relative to calving. After clotting for $45 \mathrm{~min}$ at room temperature and subsequent centrifugation (10 min, $2,000 \times g)$, the serum was obtained and stored at $-20^{\circ} \mathrm{C}$ until analysis. Biopsies from semitendinosus muscle were collected on the same days of blood sampling. The animals were sedated by intravenous injection of xylazine $(20 \mathrm{mg} / \mathrm{mL}, 0.1 \mathrm{~mL} / 100 \mathrm{~kg}$ BW; CPPharma Handels GmbH, Burgdorf, Germany) and fixed in a headlock. The biopsy area was cleaned, shaved, and disinfected with $70 \%$ isopropyl alcohol. Muscle samples were obtained under local anesthesia with procaine hydrochloride $(20 \mathrm{mg} / \mathrm{mL}, 8 \mathrm{~mL}$ per biopsy; Richter Pharma AG, Wels, Austria) by a 12-gauge $\times$ 20-cm core tissue biopsy needle with a Bard Magnum biopsy instrument (Bard Inc., Tempe, AZ). Thereafter, oxytetracycline hydrochloride was applied on the skin $(25 \mathrm{mg} / \mathrm{mL}$, Engemycin, MSD Animal Health Innovation GmbH, Schwabenheim an der Selz, Germany) and a ketoprofen injection $(100 \mathrm{mg} / \mathrm{mL}, 3 \mathrm{~mL} / 100 \mathrm{~kg} \mathrm{BW}$; Streuli Pharma AG, Uznach, Germany) was given to prevent infection and pain. Tissue samples were immediately snap-frozen in liquid nitrogen and stored at $-80^{\circ} \mathrm{C}$ until analysis.

The BA concentrations in serum and skeletal muscle were determined by liquid chromatographyelectrospray ionization-tandem mass spectrometry measurements through targeted metabolomics using the AbsoluteIDQ p180 kit (Biocrates Life Sciences AG, Innsbruck, Austria). This kit was validated according to the European Medicines Agency guidelines (EMEA Quality guidelines), which implies a proof of reproducibility within a given error range. All analyses were performed in the Helmholtz Zentrum München
$(\mathrm{GmbH})$, German Research Center for Environmental Health, Genome Analysis Center. For serum, $10 \mu \mathrm{L}$ of the thawed sample was applied directly to the assay. For muscle, frozen samples were homogenized and extracted using homogenization tubes with ceramic beads $(1.4 \mathrm{~mm})$ and a Precellys 24 homogenizer with an integrated cooling unit (PEQLAB Biotechnology $\mathrm{GmbH}$, Erlangen, Germany). For this process, $3 \mu \mathrm{L}$ of a dry ice-cooled mixture of ethanol/phosphate buffer $(85 / 15 \mathrm{vol} / \mathrm{vol})$ was added to each milligram of frozen muscle tissue. After centrifugation, $10 \mu \mathrm{L}$ of the homogenate supernatant was added to the well plate of the p180 kit. The assay procedures of the AbsoluteIDQ p180 kit, the detailed description of the tissue preparation, and the metabolite nomenclature are described in detail elsewhere (Zukunft et al., 2013, 2018). Sample handling was performed by a Hamilton Microlab STAR robot (Hamilton Bonaduz AG, Bonaduz, Switzerland) and an Ultravap nitrogen evaporator (Porvair Sciences, Leatherhead, UK), in addition to standard laboratory equipment. Mass spectrometric analyses were done on an API 4000 triple quadrupole system (Sciex Deutschland $\mathrm{GmbH}$, Darmstadt, Germany) equipped with a 1200 Series HPLC (Agilent Technologies Deutschland GmbH, Böblingen, Germany) and an HTC PAL autosampler (CTC Analytics, Zwingen, Switzerland) controlled by the software Analyst 1.6.1. Data evaluation for quantification of metabolite concentrations and quality assessment were performed with the MetIDQ software package, which is an integral part of the Absolute $I D Q$ kit. Internal standards were used as a reference for the calculation of metabolite concentrations. The concentrations of the serum samples are given in micromoles per liter, the concentrations of the tissue samples in picomoles per milligram of tissue and in micromoles per liter for the homogenates. The limit of detection was set to 3 times the values of zero samples (PBS for serum, ethanol/phosphate buffer for tissue homogenate).

\section{Statistical Analyses}

Cows were blocked according to expected calving dates. A repeated-measures model was fitted to data using the Proc MIXED procedure of SAS (version 9.4; SAS Institute Inc., Cary, NC) with first-order autoregressive covariance structure. Before analysis, all data were tested for normality of distribution by evaluating the Shapiro-Wilk statistic using the UNIVARIATE procedure of SAS. Where appropriate, data were transformed using a $\log _{10}$ transformation. The model consisted of treatment, time (sampling date), treatment $\times$ time interaction, block, and parity as the fixed effects, and cow as the random effect. The Tukey- 
$\square$ HBCS $\square$ NBCS

A

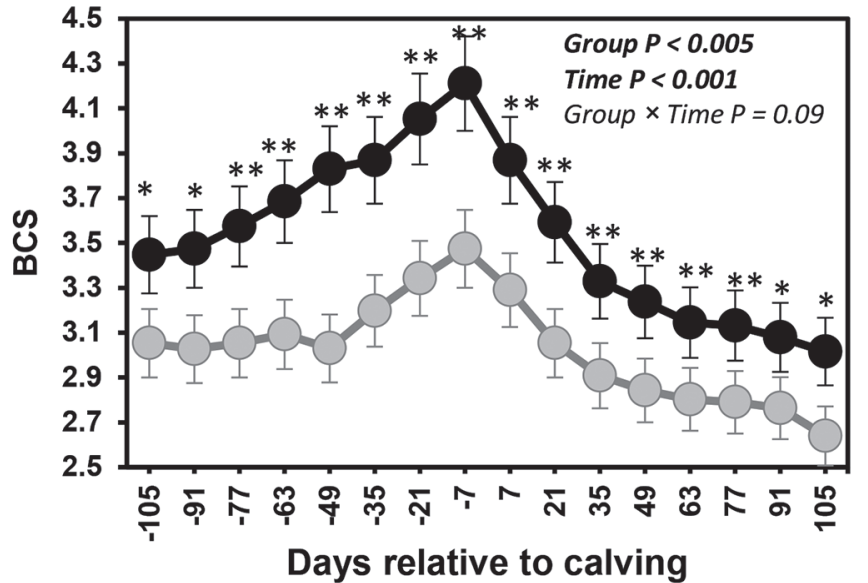

C

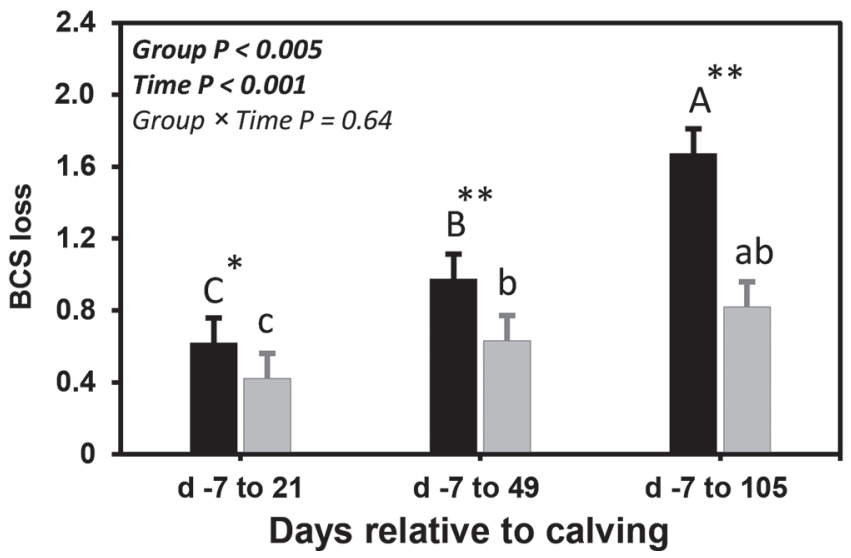

B

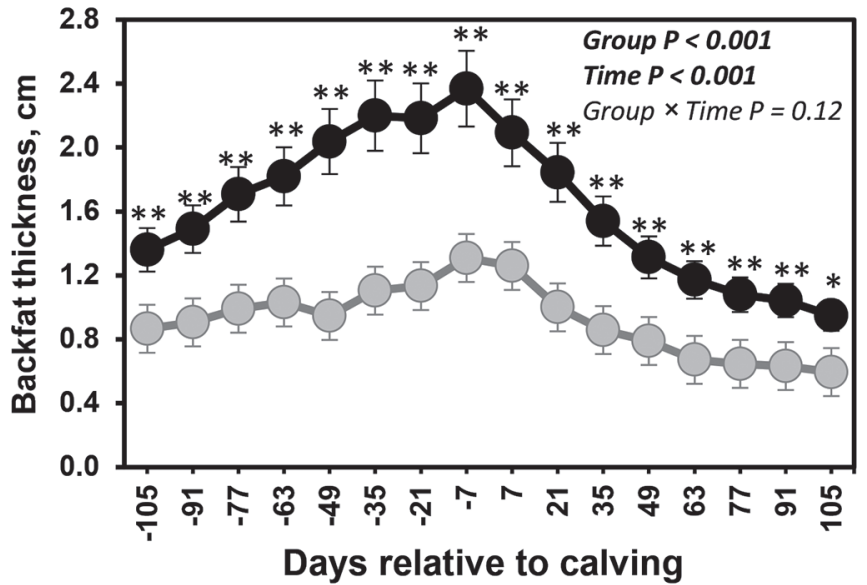

D

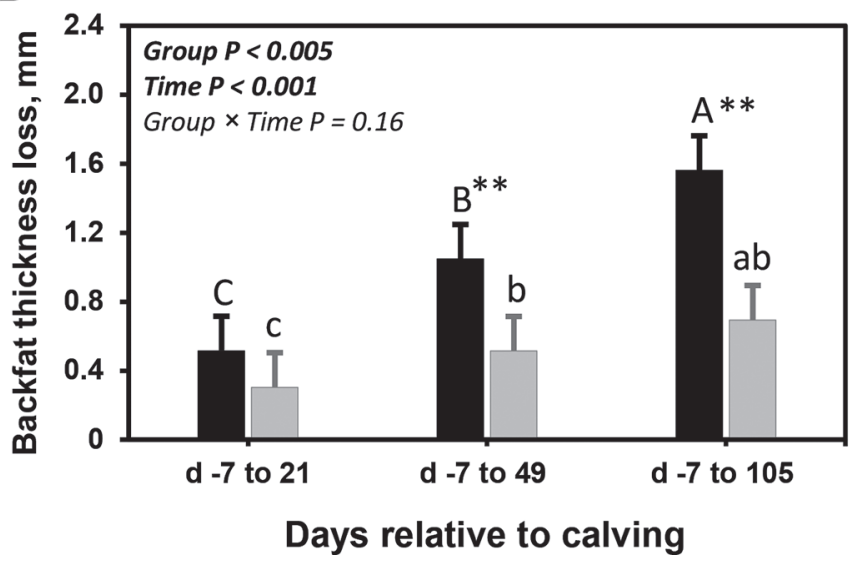

Figure 1. Changes of (A) BCS, (B) backfat thickness (BFT), (C) BCS loss, and (D) BFT loss of normal-conditioned (NBCS) and high-conditioned (HBCS) cows during the experimental period $(\mathrm{n}=18$ per treatment). Data for BCS, BFT, BCS loss, and BFT loss are from Schuh et al. (2019). Different letters indicate differences $(P<0.05)$ between the time points in the HBCS $(\mathrm{A}-\mathrm{C})$ and in the NBCS (a-c) group, respectively. Asterisks indicate a significant difference $\left(* P<0.05 ;{ }^{*} P<0.01\right)$ between groups at a given time point. Data are presented as means \pm SEM.

Kramer adjustment was applied to account for multiple comparisons. The threshold of significance was set at $P \leq 0.05$; trends were declared at $0.05<P \leq 0.10$. The correlations between the BA in the serum versus skeletal muscle were analyzed collectively for all the studied time points in GraphPad Prism (version 7.01, GraphPad Software, La Jolla, CA).

\section{RESULTS}

This study was a part of a larger study designed to investigate the performance and metabolic responses of cows differing in the mobilization of body reserves. The experimental approach to obtain such differences - that is, a preselection of cows 15 wk before calving in combination with a feeding regimen aiming to support these differences until dry-off - was successful as detailed by Schuh et al. (2019). In brief, both BCS and BFT were greater in HBCS than in NBCS cows at enrollment (d -105 antepartum) and were maintained until d 105 postpartum (Figure 1A, B). The HBCS cows also lost more BCS and BFT until d 105 postpartum (Figure $1 \mathrm{C}, \mathrm{D})$.

In the bovine samples tested herein, the metabolite coverage of the targeted metabolomics approach was used to measure $21 \mathrm{BA}$. In total, $14 \mathrm{BA}$ were detected in serum (Figure 2A) and $14 \mathrm{BA}$ in muscle tissue (Figure $2 \mathrm{~B}$ ). Out of these $14 \mathrm{BA}, 13$ were identical between serum and muscle, but histamine was only detected in muscle samples, whereas symmetric dimethylarginine (SDMA) was limited to the serum samples. Dopamine, L-3,4-dihydroxyphenylalanine, nitrotyrosine, 
methionine-sulfoxide, and cis-4-hydroxyproline were not found in either type of sample.

\section{Biogenic Amine Levels}

Serum creatinine was the most abundant BA in the serum of cows in this study (Figure 2A). The creatinine concentrations ranged between 81.0 and $99.5 \mu \mathrm{mol} / \mathrm{L}$ in serum (Figure 3A) and 597 to $704 \mathrm{pmol} / \mathrm{mg}$ tissue in skeletal muscle (Figure 4A). The circulating creatinine concentrations increased on $\mathrm{d}+3$ in both groups and tended to be greater $(P=0.08)$ in HBCS than in NBCS cows at that time point; however, the muscle creatinine concentrations did not differ between the treatments.

Taurine was the second most abundant BA in both serum and skeletal muscle (Figure 2A, B). The taurine concentrations ranged between 52.9 and $76.1 \mu \mathrm{mol} / \mathrm{L}$ in serum (Figure 3B) and 862 and $1,157 \mathrm{pmol} / \mathrm{mg}$ tissue in muscle (Figure 4B). The taurine concentrations in both serum and muscle did not differ between groups. Changes with time were limited to serum showing an increase $(P=0.01)$ during the postpartum period.

The serum concentrations of carnosine were greater $(P<0.05)$ in HBCS than in NBCS cows at $d-49$, d +21 , and $\mathrm{d}+84$, with concentrations ranging between 7.40 and $13.5 \mu \mathrm{mol} / \mathrm{L}$ (Figure 3C). The serum carnosine concentration decreased after calving $(\mathrm{d}+3)$ and subsequently increased to a higher level at $\mathrm{d}+84(P$ $<0.001$ ). In skeletal muscle, carnosine was the most abundant BA (Figure 2B), with concentrations ranging between 5,330 and $7,135 \mathrm{pmol} / \mathrm{mg}$ tissue. The carnosine concentrations in muscle (Figure $4 \mathrm{C}$ ) were greater $(P<0.05)$ in NBCS than in HBCS cows at $d-49$ but remained unchanged from late pregnancy to early lactation.

In this study, polyamines (putrescine, spermidine, and spermine) were found at very low concentrations in the serum of cows and ranged between 0.04 and 0.05 (Figure 3D), 0.02 and 0.03 (Figure 3E), and 0.02 and $0.04 \mu \mathrm{mol} / \mathrm{L}$ (Figure $3 \mathrm{~F}$ ), respectively. The serum concentrations of putrescine increased on $\mathrm{d}+84(P$ $=0.04)$ and were greater $(P<0.05)$ in HBCS than in NBCS cows. For spermidine, no treatment effects were observed, and the serum concentrations remained unchanged from late pregnancy to early lactation. The serum concentrations of spermine were not affected by the treatments but showed an increase at $\mathrm{d}+21$ $(P=0.01)$. The serum concentrations of spermine in both groups increased $(P=0.01)$ on $d+21$. In skeletal muscle, the concentrations of polyamines were similar for both groups and ranged between 1.16 and 4.21, 1.35 and 2.91 , and 3.36 and $4.02 \mathrm{pmol} / \mathrm{mg}$ tissue for putrescine, spermidine, and spermine, respectively.
The serum concentrations of $\alpha$-aminoadipic acid ( $\mathbf{\alpha - A A A}$; Figure 3G), acetylornithine (Ac-Orn; Figure $3 \mathrm{H}$ ), kynurenine (Figure 3I), and serotonin (Figure 3J) ranged between 1.8 and 3.6, 3.7 and 5.9, 2.6 and 4.9 , and 8.9 and $16.2 \mu \mathrm{mol} / \mathrm{L}$, respectively. The serum concentrations of $\alpha$-AAA were greater $(\mathrm{d}+3, P=0.01$; $\mathrm{d}+84, P=0.08)$ in HBCS than in NBCS cows. At $\mathrm{d}-49$, the serum concentrations of Ac-Orn tended to be lower $(P=0.08)$ in HBCS than in NBCS cows. The serum concentrations of serotonin did not differ between the treatments but increased at $\mathrm{d}+21$ (Figure $3 \mathrm{~J} ; P<0.001$ ). The concentrations of $\alpha$-AAA (Figure $4 \mathrm{G}$ ), Ac-Orn (Figure 4H), kynurenine (Figure 4I), and serotonin (Figure $4 \mathrm{~J}$ ) in muscle averaged 12.6, 9.5, 3.1, and $0.27 \mathrm{pmol} / \mathrm{mg}$ tissue, respectively, without group effects. The $\alpha$-AAA muscle concentrations fluctuated around calving $(P=0.01)$. The muscle concentrations of Ac-Orn, kynurenine, and serotonin remained unchanged from late pregnancy to early lactation.

Phenylethylamine (PEA) was detected at low concentrations in serum and muscle of transition cows. For PEA, no treatment effects were observed in serum (Figure $3 \mathrm{~K}$; average $0.03 \mu \mathrm{mol} / \mathrm{L}$ ), and its levels remained unchanged from late pregnancy to early lactation. In muscle tissue, the PEA concentrations ranged between 0.022 and $0.035 \mathrm{pmol} / \mathrm{mg}$ tissue and were greater $(P<$ 0.05 ) in NBCS than in HBCS cows at $d+21$ (Figure $4 \mathrm{~K})$.

The concentrations of hydroxyproline (t4-OH-Pro) ranged between 10.1 and $20.2 \mu \mathrm{mol} / \mathrm{L}$ in serum (Figure $3 \mathrm{~L}$ ) and 16.2 and $29.6 \mathrm{pmol} / \mathrm{mg}$ tissue in muscle (Figure $4 \mathrm{~L}$ ). The serum concentrations of t4-OH-Pro were greater in HBCS than in NBCS cows in early lactation $(\mathrm{d}+3, \mathrm{~d}+21$, and $\mathrm{d}+84, P<0.05)$ and increased from $\mathrm{d}-42$ until $\mathrm{d}+3$ but decreased to a lesser level at $\mathrm{d}+84(P<0.001)$. The concentrations of $\mathrm{t} 4-\mathrm{OH}-\mathrm{Pro}$ in muscle did not differ between the treatments, and the concentrations remained unchanged from late pregnancy to lactation.

Asymmetric dimethylarginine (ADMA) concentrations ranged between 0.48 and $0.85 \mu \mathrm{mol} / \mathrm{L}$ in serum (Figure $3 \mathrm{M}$ ) and 0.48 and $0.73 \mathrm{pmol} / \mathrm{mg}$ tissue in muscle (Figure 4M). The concentrations of ADMA were greater in HBCS than in NBCS cows in serum $(P<$ 0.05 ) and muscle (trend, $P=0.08$ ) at $\mathrm{d}-49$. Changes with time were limited to serum showing a decrease during the postpartum period $(P<0.001)$. Symmetric dimethylarginine (Figure $3 \mathrm{~N}$ ) ranged between 0.65 and $0.88 \mu \mathrm{mol} / \mathrm{L}$, and the concentrations were greater in NBCS than in HBCS cows at $d-49$. The serum concentrations of SDMA were greater during the postpartum period than at $\mathrm{d}-49(P=0.001)$. In muscle tissue, histamine concentrations ranged between 18 and 
(A)

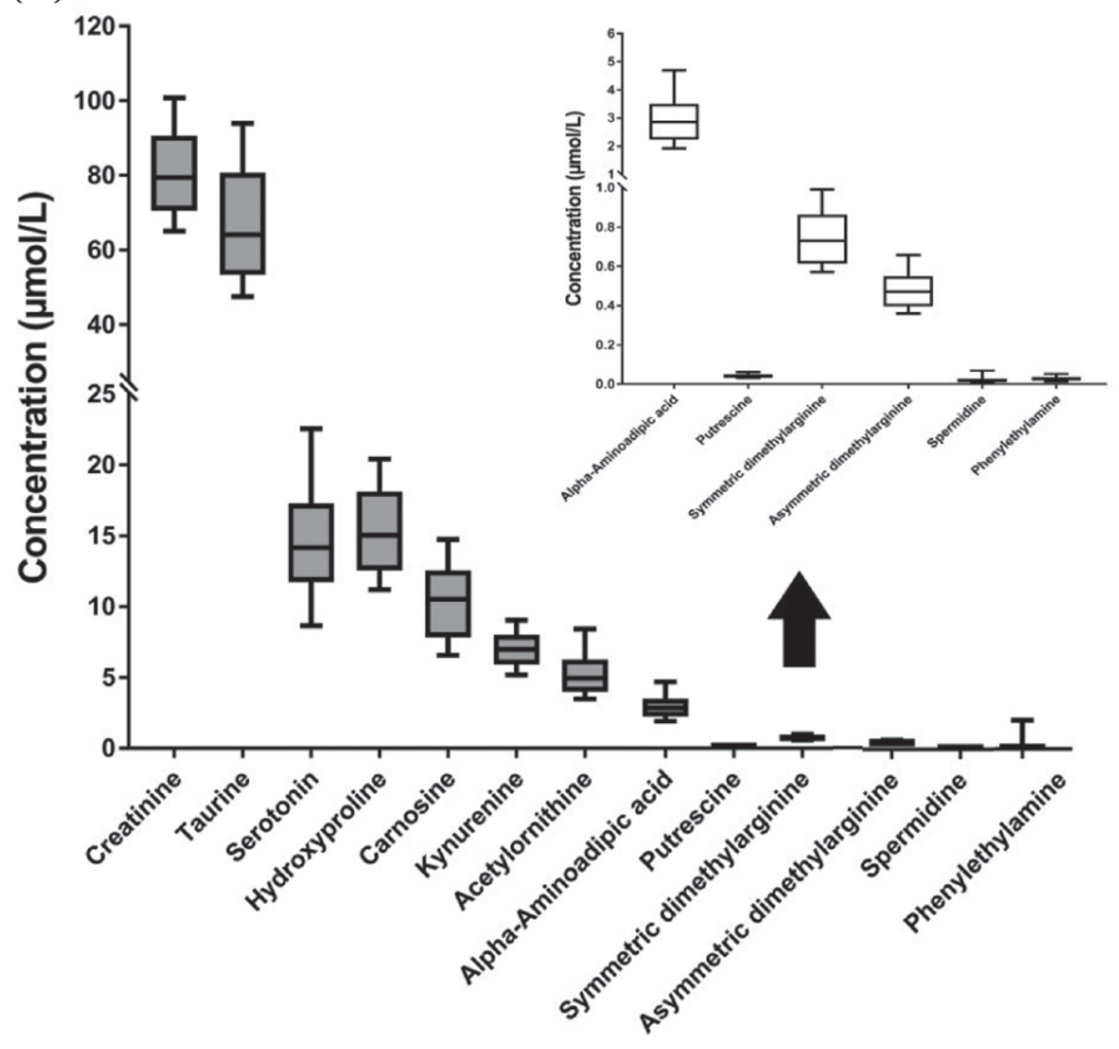

(B)

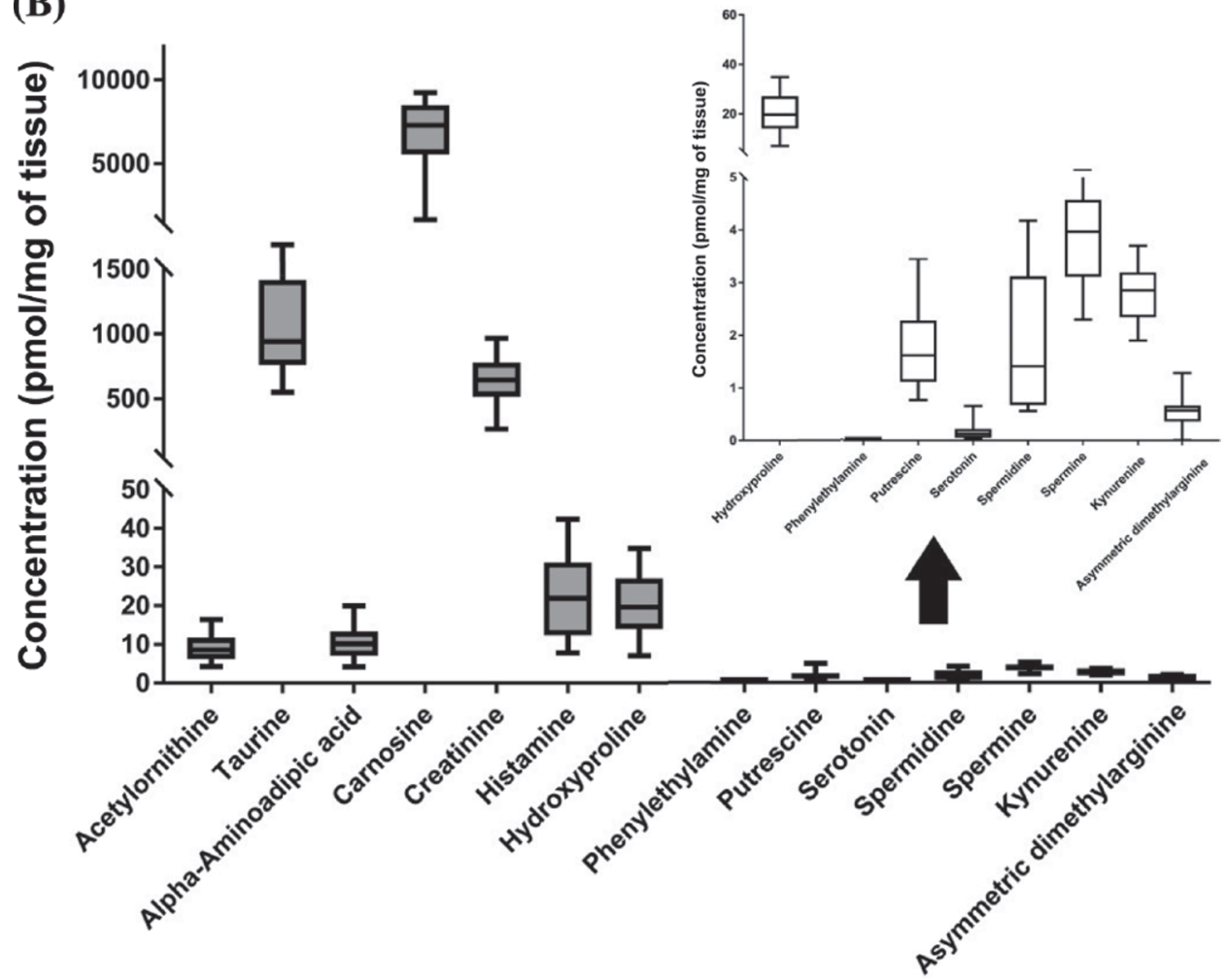

Figure 2. Concentration of biogenic amines in (A) serum and (B) skeletal muscle of dairy cows postpartum $(d+21)$. In each box plot, the heavy horizontal line crossing the box is the median, the bottom and top of the box are the lower and upper quartiles, and the whiskers follow the Tukey boxplot definition. 
$\square$ HBCS $\square$ NBCS

\section{(A) Creatinine}

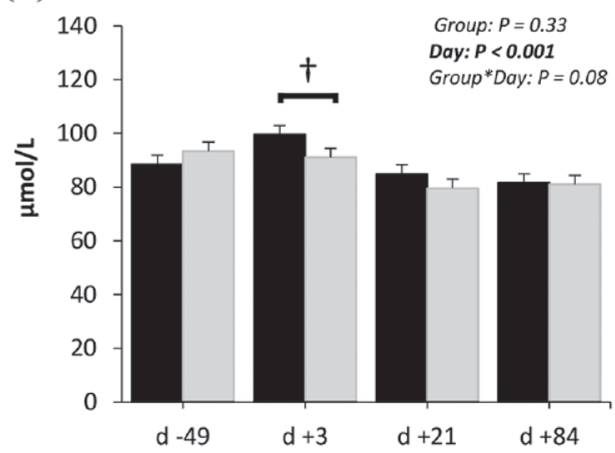

(C) Carnosine

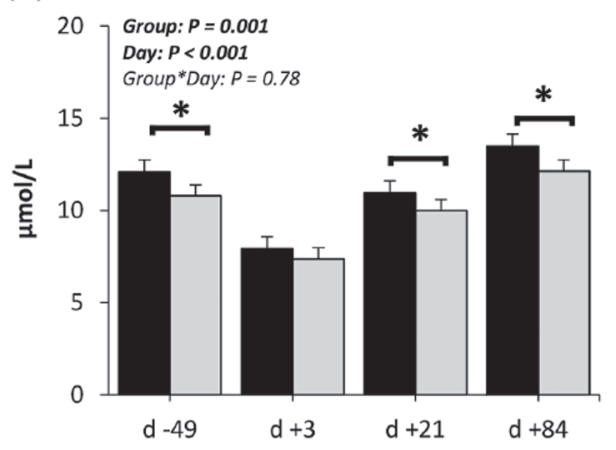

(E) Spermidine

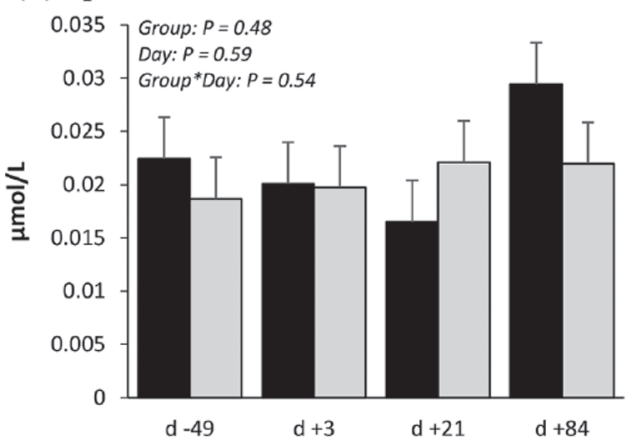

(G) Alpha-Aminoadipic acid

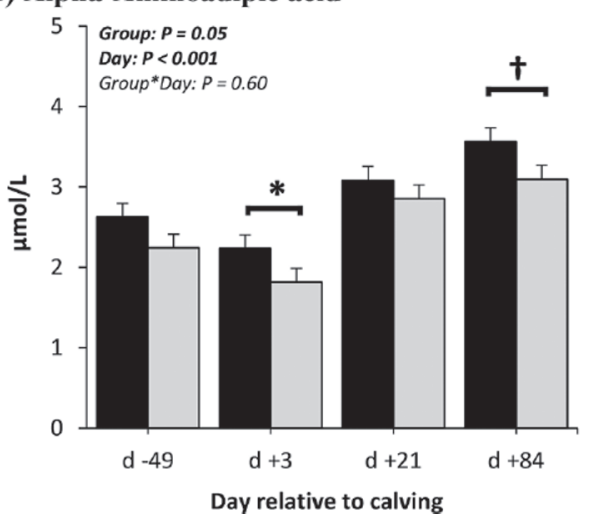

(B) Taurine

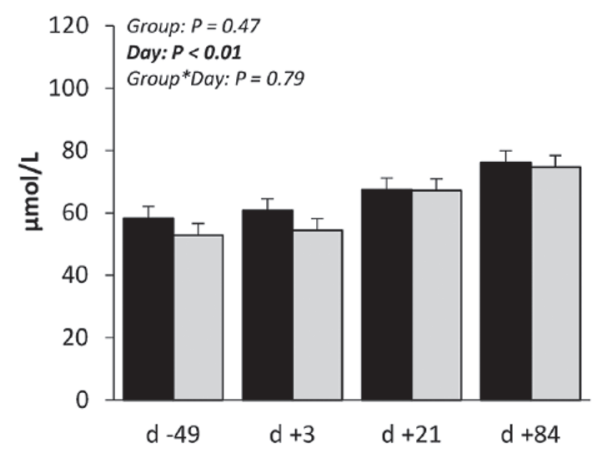

(D) Putrescine

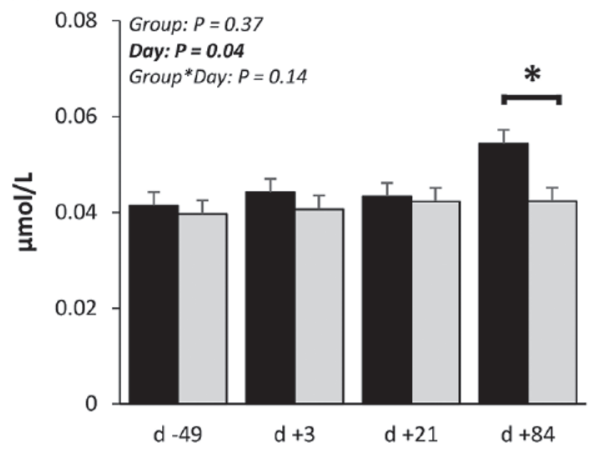

(F) Spermine

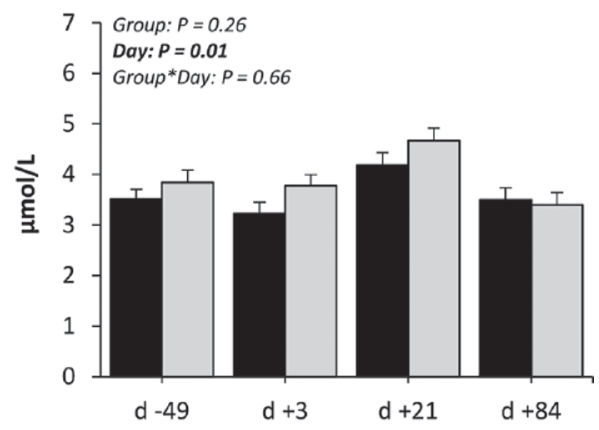

(H) Acetylornithine

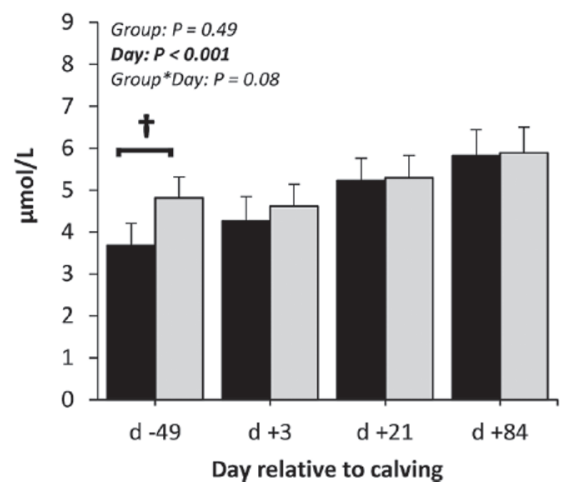

Figure 3. Longitudinal changes of biogenic amines (panels A-N) in serum of normal-conditioned (NBCS) and high-conditioned (HBCS) cows during the experimental period $(n=18$ per treatment). Symbols indicate a significant difference $(* P \leq 0.05)$ or a trend $(\dagger P<0.10)$ between groups at given time points. Data are presented as means \pm SEM. 
(I) Kynurenine

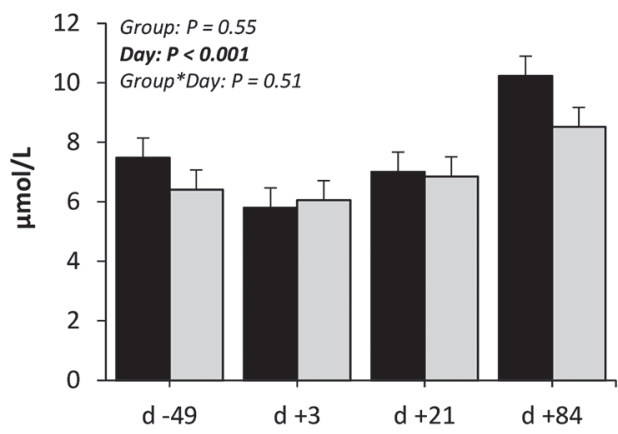

(K) Phenylethylamine

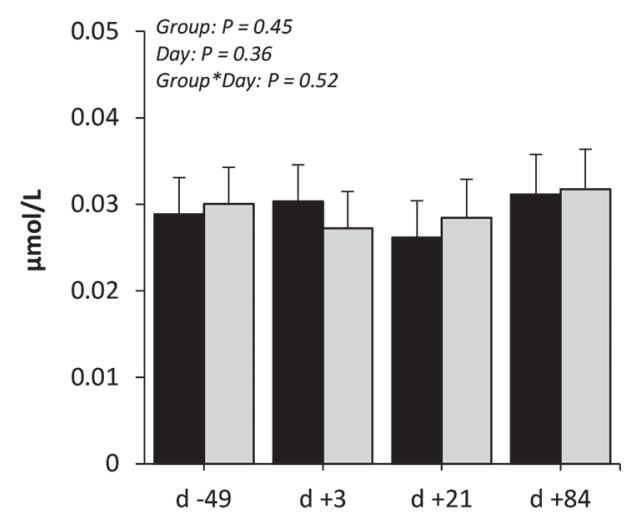

(M) Asymmetric dimethylarginine

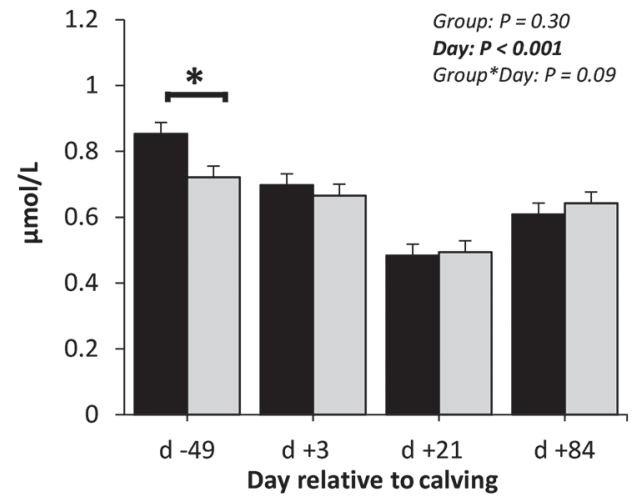

\section{(J) Serotonin}

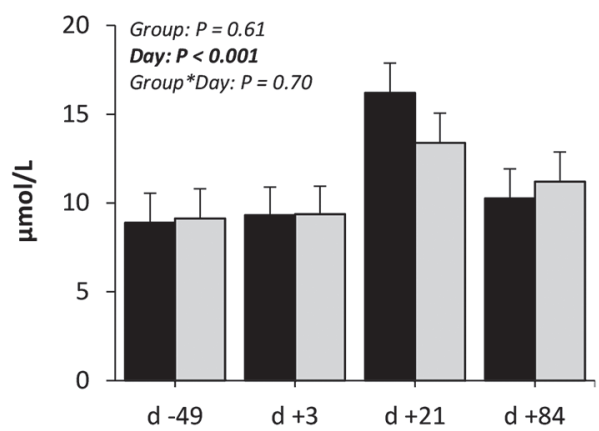

(L) Hydroxyproline

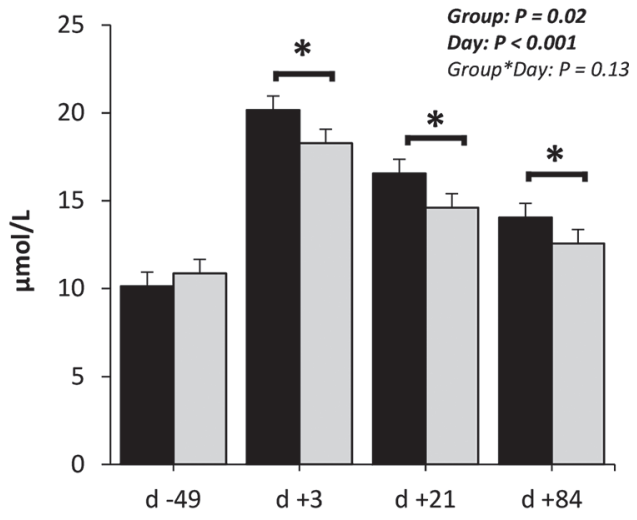

(N) Symmetric dimethylarginine

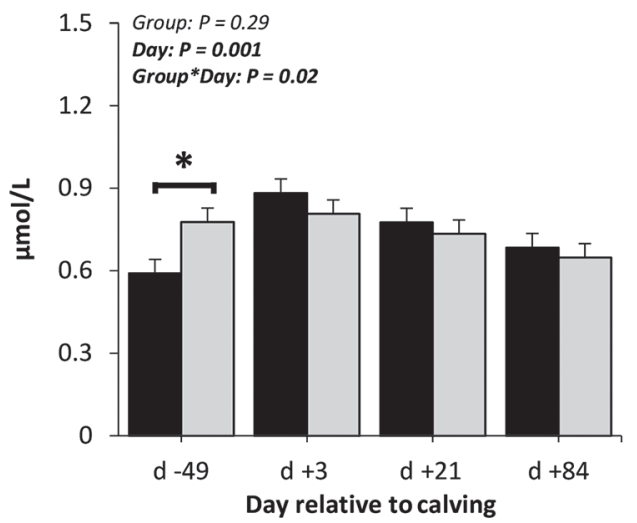

Figure 3 (Continued). Longitudinal changes of biogenic amines (panels A-N) in serum of normal-conditioned (NBCS) and high-conditioned (HBCS) cows during the experimental period $(\mathrm{n}=18$ per treatment). Symbols indicate a significant difference $(* P \leq 0.05)$ or a trend $(\dagger P<0.10)$ between groups at given time points. Data are presented as means \pm SEM.

$28 \mathrm{pmol} / \mathrm{mg}$ tissue (Figure $4 \mathrm{~N}$ ). No treatment effects were observed for histamine in muscle, and its concentrations remained unchanged from late pregnancy to early lactation.

The ratio of kynurenine to tryptophan was also calculated (Figure 5). The serum kynurenine/tryptophan ratio was higher $(P<0.05)$ in HBCS than in NBCS cows only at $\mathrm{d}+84$ (Figure $5 \mathrm{~A}$ ). The muscle kynurenine/ tryptophan ratio was similar between the treatments, and the ratio remained unchanged from late pregnancy to early lactation (Figure 5B).

\section{Correlations Between the BA Concentrations in Serum and in Muscle}

No significant correlations were found between the serum and muscle BA concentrations across all time points (Figure 6). 
$\square$ HBCS $\square$ NBCS

\section{(A) Creatinine}

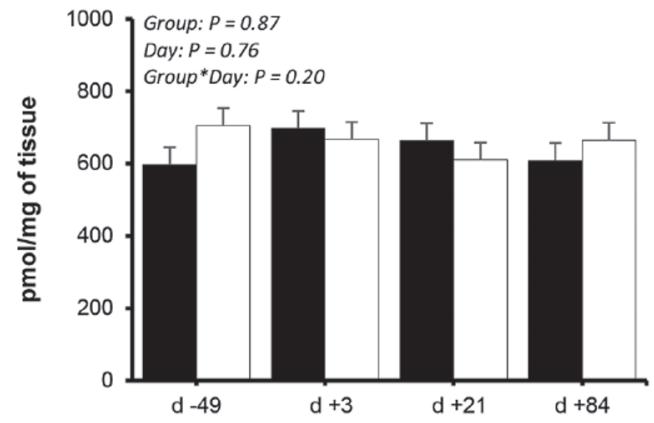

(C) Carnosine

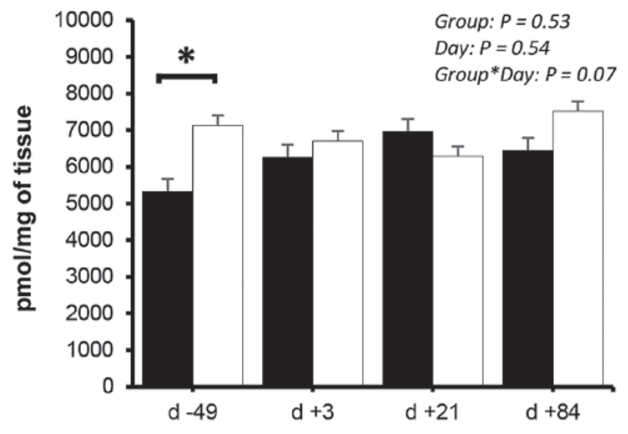

(E) Spermidine

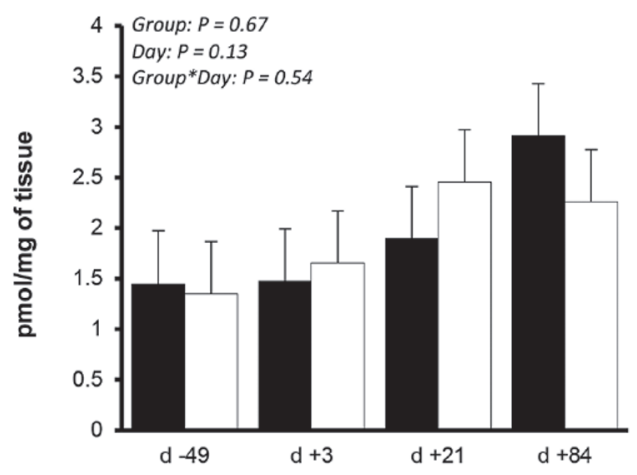

(G) Alpha-Aminoadipic acid

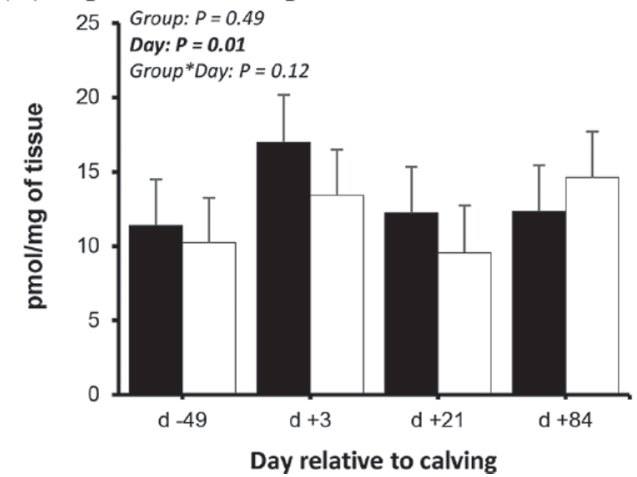

(B) Taurine

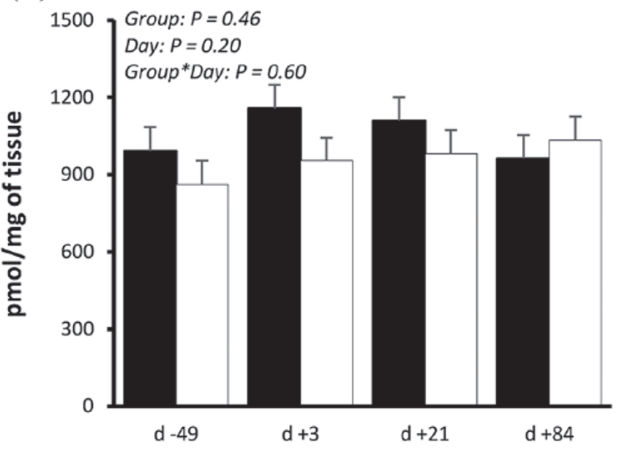

(D) Putrescine

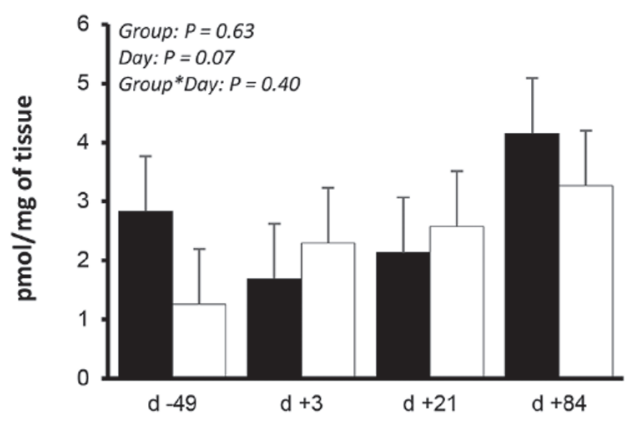

(F) Spermine

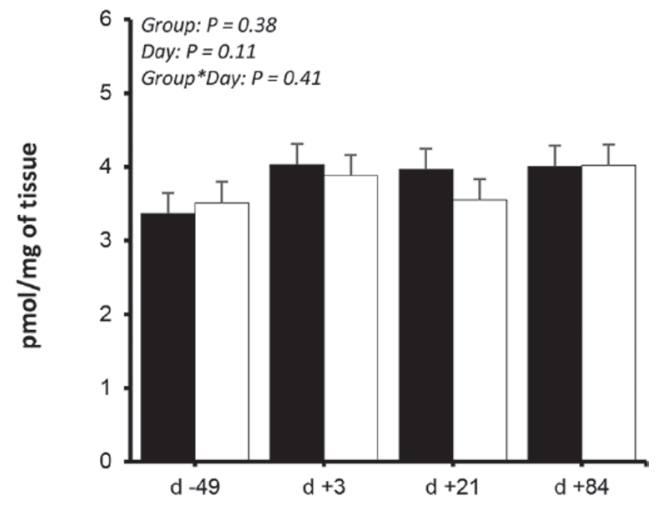

(H) Acetylornithine

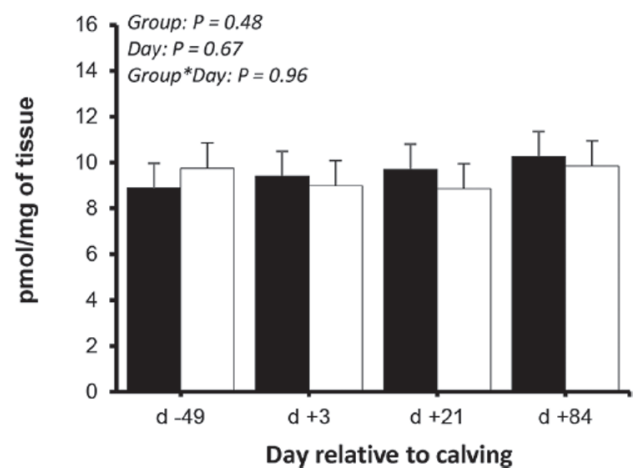

Figure 4. Longitudinal changes of biogenic amines (panels A-N) in muscle of normal-conditioned (NBCS) and high-conditioned (HBCS) cows during the experimental period $(\mathrm{n}=18$ per treatment). Symbols indicate a significant difference $(* P \leq 0.05)$ or a trend $(\dagger P<0.10)$ between groups at a given time points. Data are presented as means \pm SEM. 
(I) Kynurenine

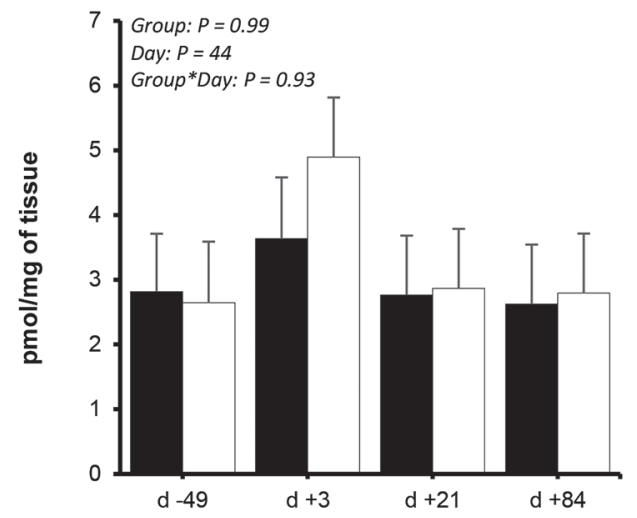

(K) Phenylethylamine

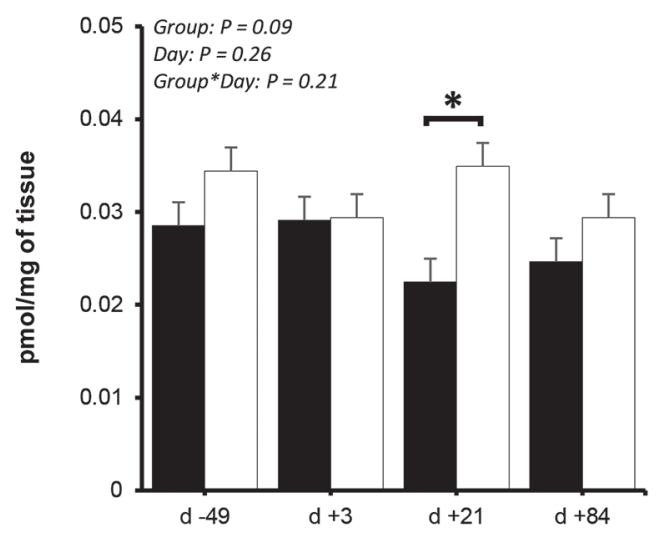

(M) Asymmetric dimethylarginine

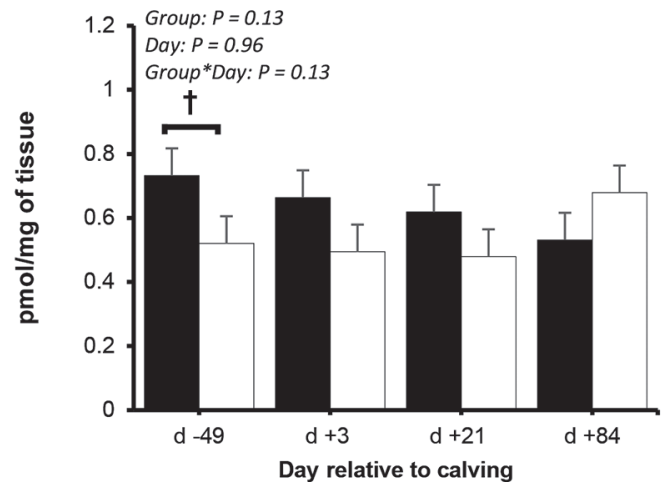

(J) Serotonin

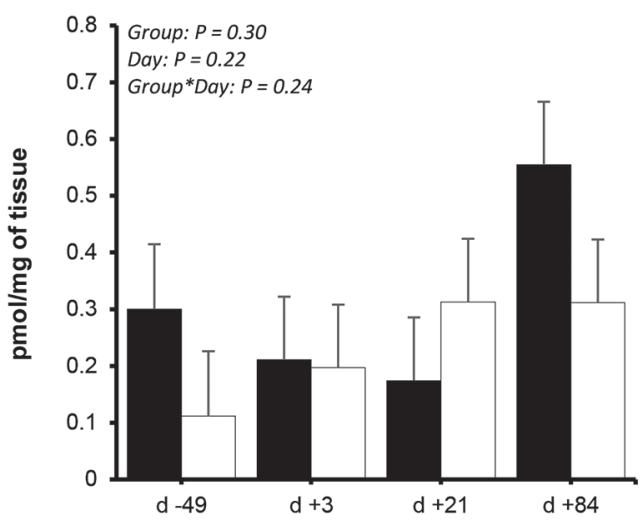

(L) Hydroxyproline

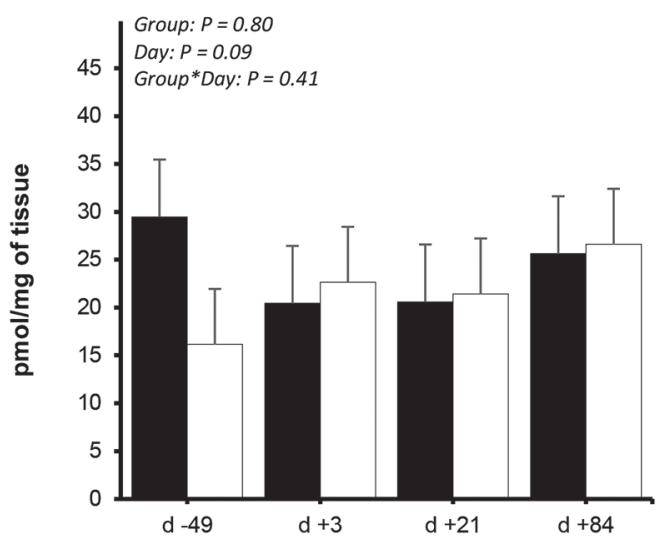

(N) Histamine

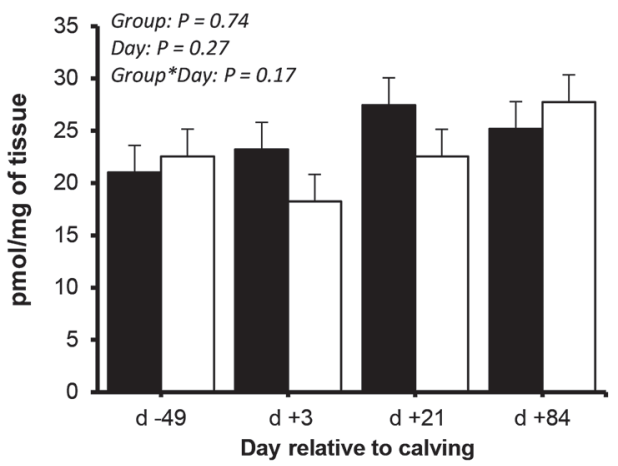

Figure 4 (Continued). Longitudinal changes of biogenic amines (panels A-N) in muscle of normal-conditioned (NBCS) and high-conditioned (HBCS) cows during the experimental period $(\mathrm{n}=18$ per treatment). Symbols indicate a significant difference $(* P \leq 0.05)$ or a trend $(\dagger P<0.10)$ between groups at a given time points. Data are presented as means \pm SEM.

\section{DISCUSSION}

In this study, we analyzed serum BA profiles relative to their counterparts in skeletal muscle of both NBCS and HBCS cows during late gestation and early lactation, and our results confirmed a complex relation- ship between adiposity and serum and muscle BA in periparturient dairy cows. Among the $14 \mathrm{BA}$ detected in serum, creatinine, putrescine, $\alpha$-AAA, t4-OH-Pro, ADMA, and SDMA were different in NBCS versus HBCS cows. In muscle tissue, despite differences in the concentrations of carnosine, PEA, t4-OH-Pro, and 
ADMA (trend) between HBCS and NBCS cows, most of the BA remained unchanged during late gestation and early lactation.

The serum creatinine concentrations measured in this study confirmed previously published results in periparturient cows that showed a decrease during the postpartum period (Pires et al., 2013). Creatinine production is continuous, and its excretion is proportional to body muscle mass. Creatinine in serum can be used as an indicator of muscle protein breakdown under conditions of normal kidney function (Phillips et al., 2003), and the decrease of serum creatinine likely reflects skeletal muscle breakdown (Bruckmaier et al., 1998). The postpartal reduction in the serum creatinine levels in this study might be partially explained by altered kidney function of the cows (Perrone et al., 1992), with the onset of lactation not being followed by an increase in glomerular filtration rate (Maltz and Silanikove, 1996). The postpartum decrease of creatinine in serum observed in our study and the group differences indicate that creatinine could enable discerning the greater mobilization of body reserves in HBCS cows during the postpartum period. Further research has reported a trend for lower plasma creatinine and a greater 3-methylhistidine/creatinine ratio in cows with low BCS as compared with medium BCS and HBCS cows, pointing to less muscle mass but more intense mobilization of muscle protein in lean cows (Pires et al., 2013). Indeed, in our study, the increase of lipolysis was verified in all animals based on increasing concentra- tions of NEFA in serum, whereby the HBCS cows had higher levels (Schuh et al., 2019).

Taurine can be derived from the diet or from endogenous production of methionine and cysteine mainly in the liver but also in other tissues (Craig, 2004), including adipose tissue (Ueki and Stipanuk, 2009). Taurine has multiple physiological functions: in muscle, it facilitates Ca-dependent excitation-contraction, and as an organic osmolyte it contributes to the regulation of cell volume (Spriet and Whitfield, 2015). It is crucial for bile acid formation and participates in the defense against oxidative stress, particularly in inflammation associated with oxidative stress (Marcinkiewicz and Kontny, 2014; Spriet and Whitfield, 2015). The antioxidant role of taurine has been attributed to its ability to scavenge reactive oxygen species (ROS) and to reduce the end products of lipid peroxidation (Balkan et al., 2002; Başaran-Küçükgergin et al., 2016). Taurine has been shown to alleviate liver lipid accumulation, at least in nonruminants (Vailati-Riboni et al., 2016), and would thus be expected to increase in the circulation of cows during the postpartum period. It is well documented that oxidative stress increases several fold through an excessive release of ROS in dairy cows after parturition (Bernabucci et al., 2005; Sordillo and Raphael, 2013). In this study, an increase in the concentration of ROS (determined by a method for detecting derivatives of reactive oxygen metabolites) was observed during the postpartum period (Schuh et al., 2019). Given the relation between taurine metabolism and obesity and insu-
(A) Serum

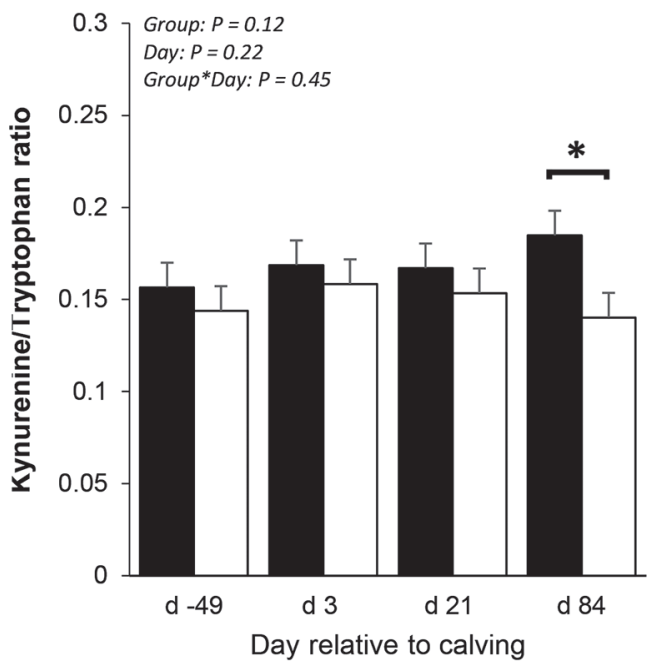

$\square$ HBCS $\square$ NBCS

(B) Skeletal muscle

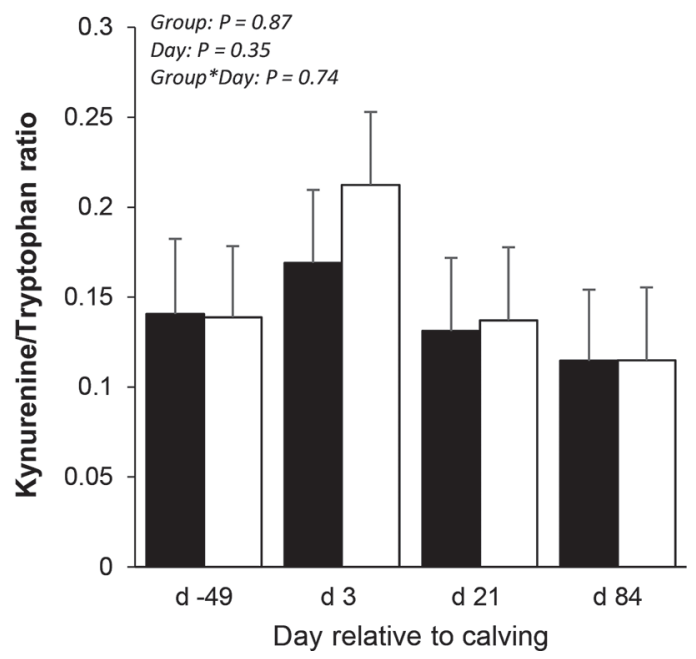

Figure 5. Longitudinal changes of kynurenine/tryptophan ratio in (A) serum and (B) muscle of normal-conditioned (NBCS) and highconditioned (HBCS) cows during the experimental period $(\mathrm{n}=18$ per treatment). Asterisks indicate a significant difference $(P<0.05)$ between groups at a given time point. Data are presented as means \pm SEM. 
lin resistance (Anuradha and Balakrishnan, 1999) with decreased blood concentrations in diabetic patients (Ito et al., 2012), we expected lower concentrations in HBCS than in NBCS cows. However, the lack of differences between the groups does not support body fat influencing taurine in the circulation of dairy cows.
The carnosine concentrations in serum measured in this study confirmed previously published results in dairy cows that showed a significant increase during the postpartum period (Huber et al., 2016; Zhang et al., 2017). Carnosine is an endogenous dipeptide ( $\beta$-alanine and L-histidine) primarily synthesized in
(A) Creatinine

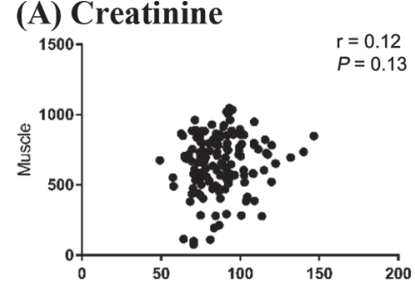

(D) Putrescine

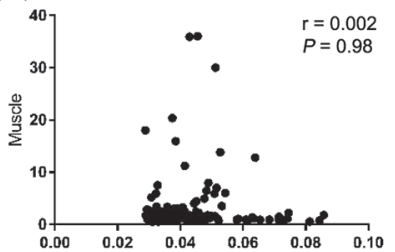

(G) Alpha-Aminoadipic acid

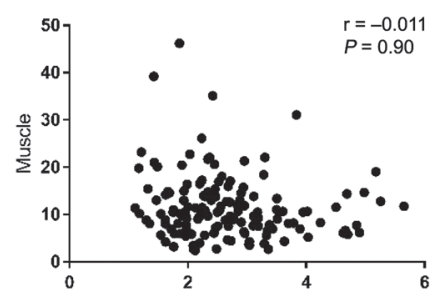

(J) Serotonin

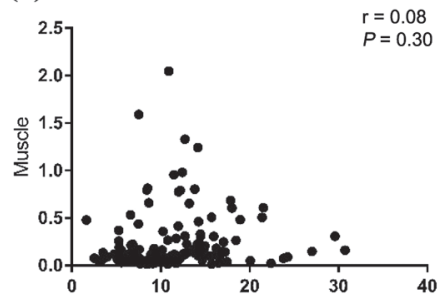

(B) Taurine

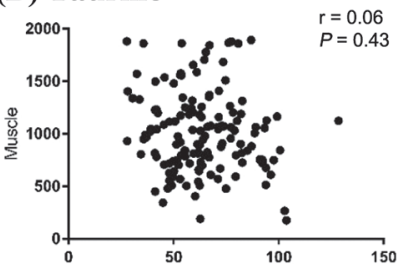

(E) Spermidine

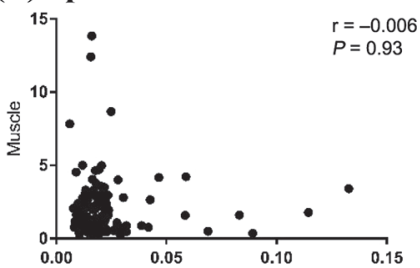

(H) Acetylornithine

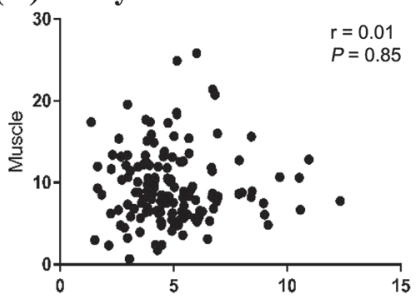

(K) Phenylethylamine

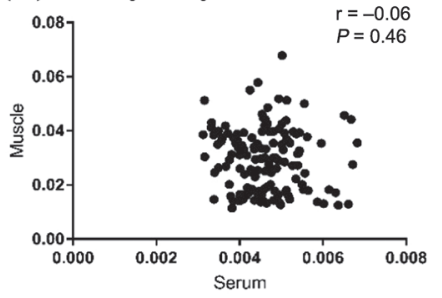

(C) Carnosine

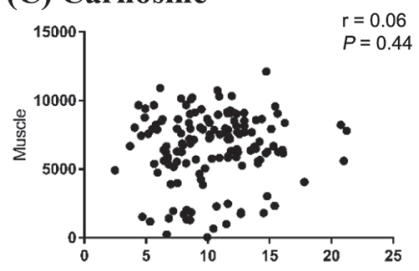

(F) Spermine

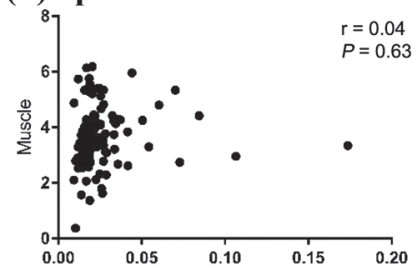

(I) Kynurenine

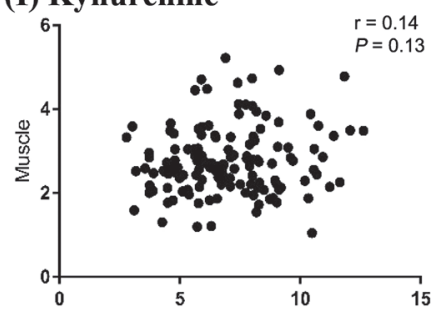

(L) Hydroxyproline

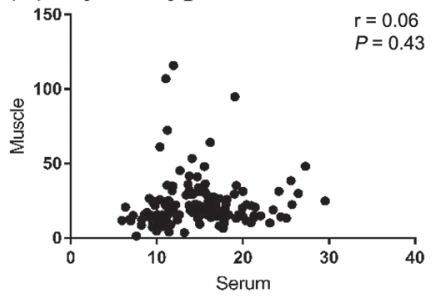

(M) Asymmetric dimethylarginine

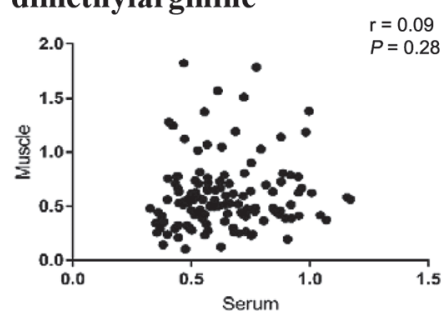

Figure 6. Correlations of biogenic amines (panels $\mathrm{A}-\mathrm{M})$ in transition cows between serum and skeletal muscle $(\mathrm{n}=36)$ across all time points. 
skeletal muscle, which has the highest concentrations in the body (Boldyrev et al., 2013). Carnosine can provide antioxidative and anti-inflammatory protection toward ROS formation (Boldyrev et al., 2013). Here, we found lower muscle carnosine levels in HBCS than in NBCS cows on $\mathrm{d}-49$. Synthesis of carnosine in skeletal muscle is potentially regulated by insulin action (Gualano et al., 2012), which could be an alternative explanation of why carnosine content was reduced in the muscle of HBCS cows. However, in the current study, no such changes were observed in the serum concentrations of insulin in HBCS cows (Schuh et al., 2019).

Polyamines (PA; putrescine, spermidine, and spermine) play major roles in diverse physiological processes, including protein synthesis and function, protection against oxidative damage, and gene expression (Pegg, 2016); however, limited data are available about the role of individual PA in these processes in the ruminant. In this study, we observed that the circulating concentrations of the 2 main polyamines (spermidine and spermine) were similar between the groups, but the serum concentrations of putrescine were greater in HBCS than in NBCS cows. Elevated putrescine levels in HBCS cows may suggest a link between body condition and activity of ornithine decarboxylase (Dong et al., 2018). The levels of individual PA in tissue are maintained and buffered by complex physiologic regulatory mechanisms (Rea et al., 2004). The concentrations of PA in muscle were reportedly increased by anabolic stimuli (Lee and MacLean, 2011). The trend for higher levels of muscle spermidine during the postpartum period might indicate a higher activity of ornithine decarboxylase, suggesting a shift toward an anabolic status.

Hepatic Lys catabolism is catalyzed by a bifunctional protein complex, aminoadipic semialdehyde synthase, that contains lysine ketoglutarate reductase and saccharopine dehydrogenase activities (Markovitz and Chuang, 1987; Papes et al., 1999). Both of these enzymes are sensitive to dietary supply of Lys in the diet (Foster et al., 1993; Blemings et al., 1998). Alpha-AAA is an intermediate in the degradation of lysine (Tucker et al., 2017), and thus the observed increase in the serum $\alpha$-AAA concentrations in HBCS cows might be due to increased hepatic Lys catabolism. This increase might be due to the greater serum concentrations of Lys in HBCS observed on d -49 (results not shown), although the observed differences largely disappeared from $\mathrm{d}+3$ onwards (i.e., after the cows received identical diets). Lysine is exclusively a ketogenic AA; the products of Lys catabolism can be used for the synthesis of ketone bodies, BHB, and acetoacetate. As reported previously from this animal experiment (Schuh et al., 2019), the postpartal increase in the serum BHB concentrations was largely limited to HBCS cows and thus hyperketo- nemia (BHB $>1.2 \mathrm{mmol} / \mathrm{L}$ ) was more frequent in HBCS cows compared with NBCS cows. Thus, we speculate that elevated $\alpha$-AAA and BHB levels in HBCS cows might be, at least in part, related to the activation of Lys degradation pathway. However, without measuring aminoadipic semialdehyde synthase abundance or activity in the present study, the exact link between $\alpha$-AAA, BHB, and hepatic Lys catabolism is unclear.

Acetylornithine has been observed in the serum of dairy cows in recent omics studies (Humer et al., 2016; Dervishi et al., 2018); however, little information appears to be available concerning its role in ruminant metabolism. Acetylornithine is an intermediate metabolite of ornithine metabolism (Zhang et al., 2017). It is also a precursor of ornithine that enters the urea cycle and participates in gluconeogenesis in dairy cows (Dervishi et al., 2018). Here, we found an increase in serum Ac-Orn levels during the postpartum period, suggesting that the hydrolysis of Ac-Orn and subsequent production of ornithine may be influenced by the metabolic status of the cow.

Kynurenine, a metabolite of tryptophan, is synthesized via the kynurenine pathway in the liver and many other tissues (Fallarino et al., 2003). The kynurenine pathway can reportedly be induced by intracellular enzymes (tryptophan 2,3-dioxygenase and indoleamine 2,3-dioxygenase) during immune responses mediated by proinflammatory cytokines (Hüther et al., 2016). In human patients, systemic inflammation related to obesity was found to be associated with the development of metabolic syndrome by induction of the tryptophankynurenine pathway. Overweight and obese adults had increased kynurenine serum levels and an increased kynurenine/tryptophan ratio. Here, we observed a higher ratio of kynurenine to tryptophan in the serum of HBCS cows only on d +84 after parturition. The elevated serum kynurenine concentrations during the postpartum period in the current study could be related to activation of hepatic tryptophan 2,3-dioxygenase and extrahepatic indoleamine 2,3-dioxygenase (Hüther et al., 2016). Zhang et al. (2017) suggested that the ratio of kynurenine to tryptophan, along with other metabolites, could be used as early predictive serum biomarkers for the risk of ketosis in transition dairy cows.

The serum serotonin concentrations measured in this study confirmed previously published results in dairy cows, showing a significant increase during the postpartum period (Moore et al., 2015; Kessler et al., 2018). Serotonin is a monoamine synthesized from L-tryptophan via a short metabolic pathway in the central nervous system and many peripheral tissues, including mammary gland and gastrointestinal tract (Mawe and Hoffman, 2013; Hernández-Castellano et 
al., 2017). Serotonin plays important roles in a wide range of biological functions, including regulation of energy metabolism and calcium homeostasis in dairy cows (Laporta et al., 2013, 2015). So far, comparable data regarding muscle serotonin concentrations in cattle are not available in the literature. In this study, we observed that the circulating levels of PEA were similar between the groups, but muscle concentrations of PEA were lower in HBCS compared with NBCS cows on d +21 . Phenylethylamine is an endogenous neuroamine and is synthesized by the action of aromatic amino acid decarboxylase on phenylalanine (Irsfeld et al., 2013). Phenylethylamine was detected at low concentrations in the serum and muscle of transition cows, which might be due to the high turnover rate and a very brief endogenous pool half-life of PEA (Pei et al., 2016). Phenylethylamine has been found in bovine mammary epithelial cells (Fusi et al., 2008) and the liver (Suzuki et al., 1980) of cows; however, no reports exist about the PEA content in other tissues of ruminants and its potential roles that would allow for a discussion about its function.

Hydroxyproline is synthesized by hydroxylation of the amino acid proline, which is extensively metabolized in the liver and can be derived from several different tissue sources such as breakdown of collagen during the involution of the uterus postpartum (Kaidi et al., 1991). In our study, we found a trend toward greater serum t4-OH-Pro concentrations in HBCS cows than in NBCS cows during early lactation along with greater t4-OH-Pro levels postpartum. However, no association between the concentrations of t4-OH-Pro in serum and excessive lipolysis in early lactation cows was observed (Humer et al., 2016). Asymmetric dimethylarginine and SDMA are both methylated analogs of L-arginine and are recognized as endogenous inhibitors of nitric oxide synthase (Vallance et al., 1992). The observed changes in the serum ADMA concentrations in this study were partially in line with previously published results showing that serum ADMA concentrations decrease from 8 wk antepartum until 4 wk postpartum in healthy cows (Zhang et al., 2017).

In the current study, we showed that changes in BA concentrations in serum during the transition period in dairy cows were not paralleled in muscle tissue. The BA concentrations in muscle were unchanged during late gestation and early lactation, with the exception of $\mathrm{\alpha}$-AAA and spermine, which fluctuated around calving in skeletal muscle. These data suggest that tissues other than skeletal muscle are likely the source of changes in the serum BA during the periparturient period of dairy cows. Moreover, the skeletal muscle compartment as a whole seems to maintain stable concentrations of BA, reflecting an adaptive mechanism to prevent abrupt changes in metabolism of cows.

\section{CONCLUSIONS}

We demonstrated that some BA change in serum with time relative to parturition. The serum concentrations of some BA (e.g., $\alpha$-AAA, t4-OH-Pro, putrescine) postpartum were higher in HBCS cows than in NBCS cows, suggesting that adiposity may be linked to the postpartum metabolism of these BA. In muscle tissue, despite differences in the levels of some BA (carnosine, $\mathrm{PEA}$, and t4-OH-Pro) between treatments, most BA remained unchanged during late gestation and early lactation. Moreover, in contrast to our hypothesis, no correlations were found between serum BA and their muscle counterparts in either group, suggesting that tissues other than skeletal muscle are contributing to the systemic alterations in BA during late gestation and early lactation in dairy cows.

\section{ACKNOWLEDGMENTS}

K. Schuh was recipient of a scholarship from the H. Wilhelm Schaumann Foundation (Hamburg, Germany). The study would not have been possible without the Educational and Research Centre for Animal Husbandry, Hofgut Neumuehle, which made the cows available and whose staff supported the animal trial.

\section{REFERENCES}

Ametaj, B. N., Q. Zebeli, F. Saleem, N. Psychogios, M. J. Lewis, S M. Dunn, J. Xia, and D. S. Wishart. 2010. Metabolomics reveals unhealthy alterations in rumen metabolism with increased proportion of cereal grain in the diet of dairy cows. Metabolomics $6: 583-594$.

Anuradha, C. V., and S. D. Balakrishnan. 1999. Taurine attenuates hypertension and improves insulin sensitivity in the fructose-fed rat, an animal model of insulin resistance. Can. J. Physiol. Pharmacol. 77:749-754

Balkan, J., Ö. Kanbağli, A. Hatipoğlu, M. Küçük, U. Çevikbas, G. Aykaç-Toker, and M. Uysal. 2002. Improving effect of dietary taurine supplementation on oxidative stress and lipid levels in plasma, liver, and aorta of rabbits fed a high cholesterol diet. Biosci. Biotechnol. Biochem. 66:1755-1758. https://doi.org/10.1271/bbb.66 .1755 .

Başaran-Küçükgergin, C., I. Bingül, M. Soluk-Tekkeşin, I. Olgaç, S. Doğru-Abbasoğlu, and M. Uysal. 2016. Effects of carnosine, taurine, and betaine pretreatments on diethylnitrosamine-induced oxidative stress and tissue injury in rat liver. Toxicol. Ind. Health 32:1405-1413. https://doi.org/10.1177/0748233714563432.

Bernabucci, U., B. Ronchi, N. Lacetera, and A. Nardone. 2005. Influence of body condition score on relationships between metabolic status and oxidative stress in periparturient dairy cows. J. Dairy Sci. 88:2017-2026. https://doi.org/10.3168/jds.S0022 -0302(05)72878-2.

Blemings, K. P., T. D. Crenshaw, and N. J. Benevenga. 1998. Mitochondrial lysine uptake limits hepatic lysine oxidation in rats fed diets containing 5, 20, or 60\% casein. J. Nutr. 128:2427-2434. 
Boldyrev, A. A., G. Aldini, and W. Derave. 2013. Physiology and pathophysiology of carnosine. Physiol. Rev. 93:1803-1845. https:/ /doi.org/10.1152/physrev.00039.2012.

Bruckmaier, R. M., L. Gregoretti, F. Jans, D. Faissler, and J. W. Blum. 1998. Longissimus dorsi muscle diameter, backfat thickness, body condition scores and skinfold values related to metabolic and endocrine traits in lactating dairy cows fed crystalline fat or free fatty acids. Zentralbl. Veterinarmed. A 45:397-410. https:// doi.org/10.1111/j.1439-0442.1998.tb00842.x.

Craig, S. A. S. 2004. Betaine in human nutrition. Am. J. Clin. Nutr. 80:539-549.

Dervishi, E., G. Zhang, R. Mandal, D. S. Wishart, and B. N. Ametaj. 2018. Metabolomics uncovers serum biomarkers that can predict the risk of retained placenta in transition dairy cows. J. Anim. Sci. 95(Suppl. 4):21-22. https://doi.org/10.2527/asasann.2017.043.

Dong, X., Z. Zhou, B. Saremi, A. Helmbrecht, Z. Wang, and J. J. Loor. 2018. Varying the ratio of Lys:Met while maintaining the ratios of Thr:Phe, Lys:Thr, Lys:His, and Lys:Val alters mammary cellular metabolites, mammalian target of rapamycin signaling, and gene transcription. J. Dairy Sci. 101:1708-1718. https://doi.org/ $10.3168 /$ jds. 2017-13351.

Fallarino, F., U. Grohmann, C. Vacca, C. Orabona, A. Spreca, M. C. Fioretti, and P. Puccetti. 2003. T cell apoptosis by kynurenines. Adv. Exp. Med. Biol. 527:183-190. https://doi.org/10.1007/978-1 -4615-0135-0_21.

Foster, A. R., P. W. D. Scislowski, C. I. Harris, and M. F. Fuller. 1993. Metabolic response of liver lysine $\alpha$-ketoglutarate reductase activity in rats fed lysine limiting or lysine excessive diets. Nutr. Res. 13:1433-1443.

Fusi, E., A. Baldi, F. Cheli, R. Rebucci, E. Ayuso, K. Sejrsen, and S. Purup. 2008. Effects of putrescine, cadaverine, spermine, spermidine and $\beta$-phenylethylamine on cultured bovine mammary epithelial cells. Ital. J. Anim. Sci. 7:131-140. https://doi.org/10.4081/ ijas.2008.131.

German Society of Nutrition Physiology (GfE). 2001. Empfehlungen zur Energie- und Nährstoffversorgung der Milchkühe und Aufzuchtrinder [Recommended energy and nutrient supply for dairy cows and heifers]. Ausschuss für Bedarfsnormen der Gesellschaft für Ernährungsphysiologie No. 8. DLG Verlag, Frankfurt am Main, Germany.

German Society of Nutrition Physiology (GfE). 2009. New equations for predicting metabolizable energy of compound feeds for cattle. Pages 143-146 in Proc. of the Society of Nutrition Physiology. DLG Verlag, Frankfurt am Main, Germany.

Gualano, B., I. Everaert, S. Stegen, G. G. Artioli, Y. Taes, H. Roschel, E. Achten, M. C. Otaduy, A. H. Junior, R. Harris, and W. Derave. 2012. Reduced muscle carnosine content in type 2, but not in type 1 diabetic patients. Amino Acids 43:21-24.

Handa, A. K., T. Fatima, and A. K. Mattoo. 2018. Polyamines: Biomolecules with diverse functions in plant and human health and disease. Front Chem. 6:10. https://doi.org/10.3389/fchem.2018 .00010 .

Hernández-Castellano, L. E., L. L. Hernandez, H. Sauerwein, and R. M. Bruckmaier. 2017. Endocrine and metabolic changes in transition dairy cows are affected by prepartum infusions of a serotonin precursor. J. Dairy Sci. 100:5050-5057. https://doi.org/10.3168/ jds.2016-12441.

Huber, K., S. Dänicke, J. Rehage, H. Sauerwein, W. Otto, U. RollKampczyk, and M. Bergen. 2016. Metabotypes with properly functioning mitochondria and anti-inflammation predict extended productive life span in dairy cows. Sci. Rep. 6:24642. https://doi .org/10.1038/srep24642.

Humer, E., A. Khol-Parisini, B. U. Metzler-Zebeli, L. Gruber, and Q. Zebeli. 2016. Alterations of the lipid metabolome in dairy cows experiencing excessive lipolysis early postpartum. PLoS One 11:e0158633. https://doi.org/10.1371/journal.pone.0158633.

Hüther, L., J. Hartwiger, C. Drong, U. Meyer, and S. Dänicke. 2016. Simultaneous determination of tryptophan, kynurenine and niacin in serum of periparturient dairy cows by high-performance liquid chromatography with diode array detection. J. Vet. Sci. Med. Diagn. 5:5-10. https://doi.org/10.4172/2325-9590.1000214.
Irsfeld, M., M. Spadafore, and B. M. Prüß. 2013. $\beta$-Phenylethylamine, a small molecule with a large impact. Webmedcentral 4:pii:4409.

Ito, T., S. W. Schaffer, and J. Azuma. 2012. The potential usefulness of taurine on diabetes mellitus and its complications. Amino Acids 42:1529-1539.

Kaidi, R., P. J. Brown, J. S. E. David, D. J. Etherington, and S. P. Robins. 1991. Uterine collagen during involution in cattle. Matrix 11:101-107.

Kalač, P., and P. Krausová. 2005. A review of dietary polyamines: Formation, implications for growth and health and occurrence in foods. Food Chem. 90:219-230. https://doi.org/10.1016/ j.foodchem.2004.03.044.

Kessler, E. C., S. K. Wall, L. L. Hernandez, R. M. Bruckmaier, and J. J. Gross. 2018. Circulating serotonin is related to the metabolic status and lactational performance at the onset of lactation in dairy cows. J. Dairy Sci. 101:11455-11460. https://doi.org/10 .3168/jds.2018-14626.

Lagishetty, C. V., and S. R. Naik. 2008. Polyamines: Potential anti-inflammatory agents and their possible mechanism of action. Int. J. Pharmacol. 40:121-125. https://doi.org/10.4103/0253-7613.42305.

Laporta, J., S. A. Moore, M. W. Peters, T. L. Peters, and L. L. Hernandez. 2013. Short communication: Circulating serotonin (5-HT) concentrations on day 1 of lactation as a potential predictor of transition-related disorders. J. Dairy Sci. 96:5146-5150. https:// doi.org/10.3168/jds.2013-6718.

Laporta, J., S. A. Moore, S. R. Weaver, C. M. Cronick, M. Olsen, A. P. Prichard, B. P. Schnell, T. D. Crenshaw, F. Penagaricano, R M. Bruckmaier, and L. L. Hernandez. 2015. Increasing serotonin concentrations alter calcium and energy metabolism in dairy cows. J. Endocrinol. 226:43-55. https://doi.org/10.1530/JOE-14-0693.

Lee, N. K. L., and H. E. MacLean. 2011. Polyamines, androgens, and skeletal muscle hypertrophy. J. Cell. Physiol. 226:1453-1460. https://doi.org/10.1002/jcp.22569.

Linares, D. M., M. C. Martın, V. Ladero, M. A. Alvarez, and M. Fernandez. 2011. Biogenic amines in dairy products. Crit. Rev. Food Sci. Nutr. 51:691-703. https://doi.org/10.1080/10408398 .2011.582813.

Lockwood, D. H., and L. E. East. 1974. Studies of the insulin-like actions of polyamines on lipid and glucose metabolism in adipose tissue cells. J. Biol. Chem. 249:7717-7722.

Madeo, F., T. Eisenberg, S. Büttner, C. Ruckenstuhl, and G. Kroemer. 2010. Spermidine: A novel autophagy inducer and longevity elixir. Autophagy 6:160-162. https://doi.org/10.4161/auto.6.1.10600.

Maltz, E., and N. Silanikove. 1996. Kidney function and nitrogen balance of high yielding dairy cows at the onset of lactation. J. Dairy Sci. 79:1621-1626. https://doi.org/10.3168/jds.S0022 $-0302(96) 76525-6$.

Marcinkiewicz, J., and E. Kontny. 2014. Taurine and inflammatory diseases. Amino Acids 46:7-20. https://doi.org/10.1007/s00726 -012-1361-4.

Markovitz, P. J., and D. T. Chuang. 1987. The bifunctional aminoadipic semialdehyde synthase in lysine degradation: Separation of reductase and dehydrogenase domains by limited proteolysis and column chromatography. J. Biol. Chem. 262:9353-9358.

Mawe, G. M., and J. M. Hoffman. 2013. Serotonin signaling in the gastrointestinal tract: Functions, dysfunctions, and therapeutic targets. Nat. Rev. Gastroenterol. Hepatol. 10:473-486. https://doi .org/10.1038/nrgastro.2013.105.

Medina, M. A., J. L. Urdiales, C. Rodríguez-Caso, F. J. Ramírez, and F. Sánchez-Jiménez. 2003. Biogenic amines and polyamines: Similar biochemistry for different physiological missions and biomedical applications. Crit. Rev. Biochem. Mol. Biol. 38:23-59. https:// doi.org/10.1080/713609209.

Miller, G. M. 2011. The emerging role of trace amine associated receptor 1 in the functional regulation of monoamine transporters and dopaminergic activity. J. Neurochem. 116:164-176. https:// doi.org/10.1111/j.1471-4159.2010.07109.x

Moore, S. A., J. Laporta, T. D. Crenshaw, and L. L. Hernandez. 2015. Patterns of circulating serotonin and related metabolites in multiparous dairy cows in the peripartum period. J. Dairy Sci. 98:3754-3765. 
Naumann, C., and R. Bassler. 2004. Die chemische Untersuchung von Futtermitteln. VDLUFA-Verlag, Darmstadt, Germany.

Papes, F., E. L. Kemper, G. Cord-Neto, F. Langone, and P. Arruda. 1999. Lysine degradation through the saccharopine pathway in mammals: Involvement of both bifunctional and monofunctional lysine-degrading enzymes in mouse. Biochem. J. 344:555-563.

Pegg, A. E. 2016. Functions of polyamines in mammals. J. Biol. Chem. 291:14904-14912. https://doi.org/10.1074/jbc.R116.731661.

Pei, Y., A. Asif-Malik, and J. J. Canales. 2016. Trace amines and the trace amine-associated receptor 1: Pharmacology, neurochemistry and clinical implications. Front. Neurosci. 10:148-165. https://doi .org/10.3389/fnins.2016.00148.

Perrone, R. D., N. E. Madias, and A. S. Levey. 1992. Serum creatinine as an index of renal function: New insights into old concepts. Clin. Chem. 38:1933-1953.

Phillips, G. J., T. L. Citron, J. S. Sage, K. A. Cummins, M. J. Cecava, and J. P. McNamara. 2003. Adaptations in body muscle and fat in transition dairy cattle fed differing amounts of protein and methionine hydroxy analog. J. Dairy Sci. 86:3634-3647. https://doi.org/ 10.3168/jds.S0022-0302(03)73969-1.

Phuntsok, T., M. A. Froetschel, H. E. Amos, M. Zheng, and Y. W. Huang. 1998. Biogenic amines in silage, apparent postruminal passage, and the relationship between biogenic amines and digestive function and intake by steers. J. Dairy Sci. 81:2193-2203. https:// doi.org/10.3168/jds.S0022-0302(98)75798-4.

Pires, J. A., C. Delavaud, Y. Faulconnier, D. Pomies, and Y. Chilliard. 2013. Effects of body condition score at calving on indicators of fat and protein mobilization of periparturient Holstein-Friesian cows. J. Dairy Sci. 96:6423-6439. https://doi.org/10.3168/jds.2013 -6801 .

Rea, G., A. Bocedi, and M. Cervelli. 2004. What is the biological function of the polyamines? IUBMB Life 56:167-169. https://doi.org/ $10.1080 / 15216540410001673996$.

Sadasivan, S. K., B. Vasamsetti, J. Singh, V. V. Marikunte, A. M. Oommen, M. R. Jagannath, and R. Pralhada Rao. 2014. Exogenous administration of spermine improves glucose utilization and decreases bodyweight in mice. Eur. J. Pharmacol. 729:94-99. https://doi.org/10.1016/j.ejphar.2014.01.073.

Saleem, F., B. N. Ametaj, S. Bouatra, R. Mandal, Q. Zebeli, S. M. Dunn, and D. S. Wishart. 2012. A metabolomics approach to uncover the effects of grain diets on rumen health in dairy cows. J. Dairy Sci. 95:6606-6623. https://doi.org/10.3168/jds.2012-5403.

Schuh, K., H. Sadri, S. Häussler, C. Urh, C. Koch, J. Frahm, S. Dänicke, G. Dusel, and H. Sauerwein. 2019. Comparison of performance and metabolism from late pregnancy to early lactation in dairy cows with elevated versus normal body condition at dry-off. Animal 7:1-11. https://doi.org/10.1017/S1751731118003385.

Sordillo, L. M., and W. Raphael. 2013. Significance of metabolic stress, lipid mobilization, and inflammation on transition cow disorders. Vet. Clin. North Am. Food Anim. Pract. 29:267-278. https://doi .org/10.1016/j.cvfa.2013.03.002.

Spriet, L. L., and J. Whitfield. 2015. Taurine and skeletal muscle function. Curr. Opin. Clin. Nutr. Metab. Care 18:96-101. https://doi .org/10.1097/MCO.0000000000000135.
Steidlová, S., and P. Kalač. 2002. Levels of biogenic amines in maize silages. Anim. Feed Sci. Technol. 102:197-205.

Steidlová, S., and P. Kalač. 2003. The effects of using lactic acid bacteria inoculants in maize silage on the formation of biogenic amines. Arch. Tierernahr. 57:359-368.

Suzuki, OKatsumata, Y., and M. Oya. 1980. Short communication: Oxidation of p-phenylethylamine by both types of monoamine oxidase: Examination of enzymes in brain and liver mitochondria of eight species. J. Neurochem. 3-5:1298-1301.

Tucker, H. A., M. D. Hanigan, J. Escobar, P. H. Doane, and S. S. Donkin. 2017. Hepatic expression of aminoadipate semialdehyde synthase is unchanged by postruminal lysine supply in lactating dairy cows. J. Dairy Sci. 100:1009-1018. https://doi.org/10.3168/ jds.2016-10972.

Ueki, I., and M. H. Stipanuk. 2009. 3T3-L1 adipocytes and rat adipose tissue have a high capacity for taurine synthesis by the cysteine dioxygenase/cysteinesulfinate decarboxylase and cysteamine dioxygenase pathways. J. Nutr. 139:207-214. https://doi.org/10 $.3945 /$ jn.108.099085.

Vailati-Riboni, M., S. Meier, C. R. Burke, J. K. Kay, M. D. Mitchell, C. G. Walker, M. A. Crookenden, A. Heiser, S. L. Rodriguez-Zas, J. R. Roche, and J. J. Loor. 2016. Prepartum body condition score and plane of nutrition affect the hepatic transcriptome during the transition period in grazing dairy cows. BMC Genomics 17:854 https://doi.org/10.1186/s12864-016-3191-3.

Vallance, P., A. Leone, A. Calver, J. Collier, and S. Moncada. 1992. Accumulation of an endogenous inhibitor of nitric oxide synthesis in chronic renal failure. Lancet 339:572-575. https://doi.org/10 .1016/0140-6736(92)90865-Z.

Vuohelainen, S., E. Pirinen, M. Cerrada-Gimenez, T. A. Keinänen, A. Uimari, M. Pietilä, A. R. Khomutov, J. Jänne, and L. Alhonen. 2010. Spermidine is indispensable in differentiation of 3T3-L1 fibroblasts to adipocytes. J. Cell. Mol. Med. 14:1683-1692. https:// doi.org/10.1111/j.1582-4934.2009.00808.x.

Wang, T. J., D. Ngo, N. Psychogios, A. Dejam, M. G. Larson, R. S. Vasan, A. Ghorbani, J. O'Sullivan, S. Cheng, E. P. Rhee, S. Sinha, E. McCabe, C. S. Fox, C. J. O'Donnell, J. E. Ho, J. C. Florez, M. Magnusson, K. A. Pierce, A. L. Souza, Y. Yu, C. Carter, P. E. Light, O. Melander, C. B. Clish, and R. E. Gerszten. 2013. 2-Aminoadipic acid is a biomarker for diabetes risk. J. Clin. Invest. 123:4309-4317. https://doi.org/10.1172/JCI64801.

Zhang, G., E. Dervishi, S. M. Dunn, R. Mandal, P. Liu, B. Han, D. S. Wishart, and B. N. Ametaj. 2017. Metabotyping reveals distinct metabolic alterations in ketotic cows and identifies early predictive serum biomarkers for the risk of disease. Metabolomics 13:43-58. https://doi.org/10.1007/s11306-017-1180-4

Zukunft, S., C. Prehn, C. Röhring, G. Möller, M. Hrabe de Angelis, J. Adamski, and J. Tokarz. 2018. High-throughput extraction and quantification method for targeted metabolomics in murine tissues. Metabolomics 14:18.

Zukunft, S., M. Sorgenfrei, C. Prehn, G. Möller, and J. Adamski. 2013. Targeted metabolomics of dried blood spot extracts. Chromatographia 76:1295-1305. 